\title{
Synthesis and aromatisation of cyclic enediyne-containing amino acids $\uparrow$
}

\author{
Jasper Kaiser, ${ }^{a}$ Bart C. J. van Esseveldt, ${ }^{a}$ Margot J. A. Segers, ${ }^{a}$ Floris L. van Delft, ${ }^{a}$ Jan M. M. Smits, ${ }^{a}$ \\ Sam Butterworth ${ }^{b}$ and Floris P. J. T. Rutjes $* a$
}

\author{
Received 1st September 2008, Accepted 5th November 2008 \\ First published as an Advance Article on the web 10th December 2008 \\ DOI: 10.1039/b815176h
}

A series of cyclic enediyne-containing amino acids with ring sizes varying from 10 to 12 atoms have been prepared starting from propargylglycine and homopropargylglycine. Their reactivity towards Bergman cyclisation under elevated temperatures has been explored. The enediynes displayed marked differences in cyclisation half-lives depending on the olefinic substituent and the ring size. A potential candidate for incorporation into peptides has been identified.

\section{Introduction}

Enediyne cytotoxins rank among Nature's most powerful antitumour and antibiotic agents. First discovered in the mid 1980 's, ${ }^{1}$ they triggered a considerable interest in the enediyne chemistry and biology. Upon thermal activation, the enediyne $((Z)-3-$ ene-1,5-diyne) moiety (coined "warhead") ${ }^{2}$ contained in these compounds undergoes a symmetry-allowed rearrangement, the so-called Bergman cyclisation reaction (BC), causing conversion into the corresponding benzene derivative. ${ }^{3}$ The intermediate benzenoid $\sigma, \sigma-1,4$-diradical (sometimes called para-benzyne) is capable of abstracting hydrogen radicals from nearby DNA, ultimately resulting in single and double strand cleavage. ${ }^{1}$

All natural enediynes have their "warhead" pre-activated by being incorporated in a strained ring system thereby increasing the reactivity towards cycloaromatisation. A few enediynes have been approved for chemotherapeutic use, the first ever being neocarzinostatin (Japan, 1996). ${ }^{4}$ Mylotarg $^{\circledR}$, a conjugate of a monoclonal antibody and the natural enediyne calicheamicin $\gamma_{1}{ }^{\mathrm{I}}$, has been approved by the FDA in 2006 for the treatment of acute myeloid leukemia. ${ }^{5}$ Due to the complexity and toxicity of the naturally occurring enediynes, the design and synthesis of readily accessible model systems mimicking their chemical and biological function has become an important research target. ${ }^{6}$ Examples of some model enediynes related to the current study are shown in Fig. 1. The group of Basak prepared the cyclic nitrogen-containing enediyne 1 and conducted kinetic studies. ${ }^{7}$ Banfi et al. addressed the general problem of selectively triggering the $\mathrm{BC}$ by fusing a cyclic enediyne to a $\beta$-lactam moiety (2) which serves as a locking device that can be opened in a slightly basic environment. ${ }^{8}$

The first cyclic enediyne-containing amino acids published in literature were assembled by Du et al., ${ }^{9}$ but our group has also

Institute for Molecules and Materials, Radboud University Nijmegen, Heyendaalseweg 135, 6525, AJ Nijmegen, The Netherlands. E-mail: F.Rutjes@science.ru.nl; Fax: +31 24365 3393; Tel: +31 243653202

${ }^{b}$ AstraZeneca $R \& D$, Alderley Park, Macclesfield, Cheshire, SK10 4TG, United Kingdom

$\dagger$ Electronic supplementary information (ESI) available: NMR spectra of compounds 14-19, 23-26, 28, 29, 31-36; crystal data and structure refinements for compounds $4,19,29$ and 34 . CCDC reference numbers 237705 (4), 698982 (29), 698983 (19) and CCDC 698984 (34). For ESI and crystallographic data in CIF or other electronic format see DOI: $10.1039 / \mathrm{b} 815176 \mathrm{~h}$

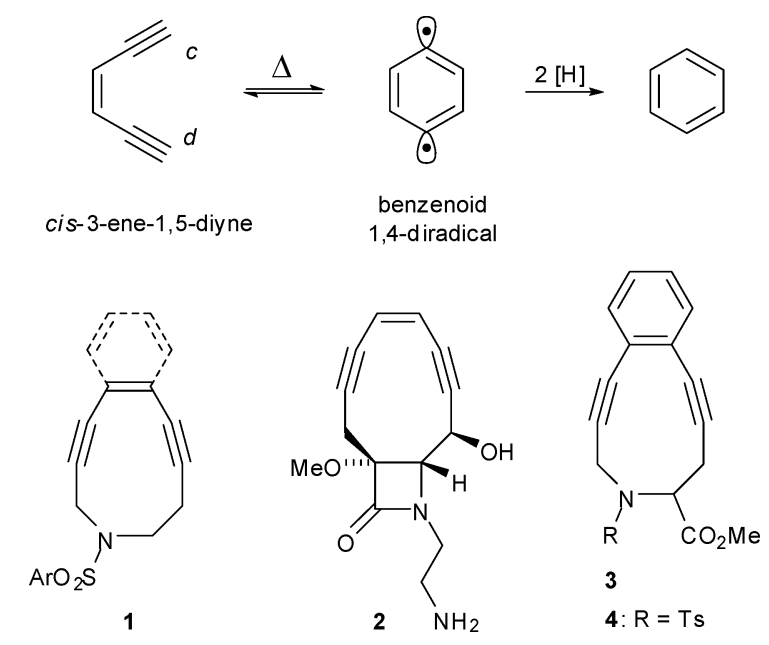

Fig. 1 The Bergman cyclisation and some $N$-heterocyclic enediynes.

conducted research into this compound class. ${ }^{10} \mathrm{Du}$ et al. reported the synthesis of a series of 10-membered benzofused enediynes (3) and studied their half-lives. Additionally, the tosyl-protected variant 4 was shown to be capable of cleaving supercoiled DNA $\left(\Phi-X\right.$ DNA) upon incubation at $37^{\circ} \mathrm{C}$ for $24 \mathrm{~h}$ at concentrations of $10 \mu \mathrm{M}$ and higher.

Owing to the powerful DNA cleaving and thus potential antitumour activities of the enediynes, expanding the series of readily accessible enediyne-containing amino acids could be of general interest, especially in combination with suitable DNA targeting probes. The versatile and well-described chemistry of amino acids would ensure multiple possibilities for incorporation of the amino acids in peptides or other targeting devices. In this report, we disclose the synthesis and evaluation of a series of 10-, 11- and 12-membered cyclic enediyne-containing amino acids 5 (Scheme 1) as well as their cycloaromatisation products. Furthermore, we report the unexpected racemisation of the title compounds (specifically 4) occurring in the final step of their syntheses even under mild conditions.

Retrosynthetically, the target compounds $\mathbf{5}$ should be accessible via intramolecular $\mathrm{C}-\mathrm{N}$ bond formation from the open chain enediynes 6. ${ }^{9}$ We envisaged to assemble these cyclisation precursors by means of Sonogashira coupling ${ }^{11}$ of the appropriate acetylenic amino acids $7^{12}$ with enynes 8 . The latter compounds, 
<smiles>[R]NC([14CH2]C#Cc1ccccc1C#CC(=O)O)O[R]</smiles>

5<smiles>C=CC=C</smiles><smiles>[X]c1ccccc1CCCC</smiles><smiles>[X]c1ccccc1C#CC(O)O</smiles>
haloge 8 $\mathrm{n}$

Scheme 1 Retrosynthesis of the title compounds.

in turn, would be constructed by Sonogashira reactions starting from $(Z)$-configured vicinal vinyl dihalides.

\section{Results and discussion}

Initially, we studied the ring closure via intramolecular mesylate displacement (Scheme 2). ${ }^{13}$

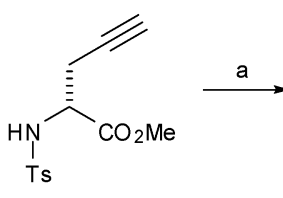

$(R)-9$

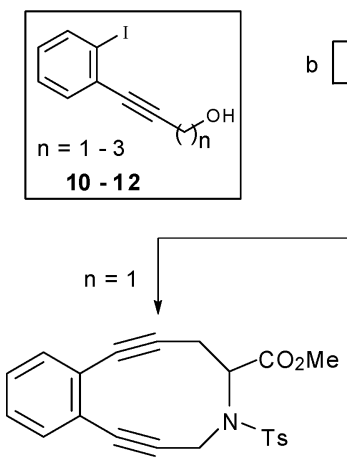

$( \pm)-4(75 \%)$

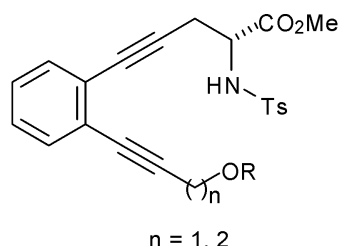

$\mathrm{b}[(R)-13(89 \%),(R)-14(71 \%): \mathrm{R}=\mathrm{H}$ $(R)-15(86 \%),(R)-16(93 \%): \mathrm{R}=\mathrm{Ms}$

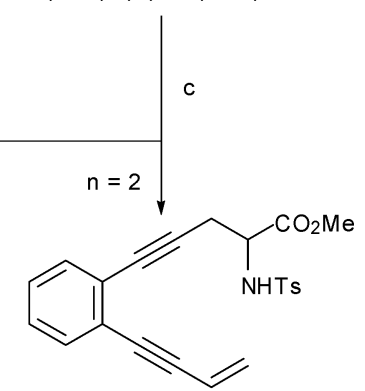

$( \pm)-17(76 \%)$
Scheme 2 Mesylate displacement strategy. Reagents and conditions: (a) Haloenynol $\mathbf{1 0}(\mathrm{n}=1)$ or $\mathbf{1 1}(\mathrm{n}=2), \mathrm{PdCl}_{2}\left(\mathrm{PPh}_{3}\right)_{2}$ (cat.), $\mathrm{CuI}$ (cat.), $\mathrm{Et}_{2} \mathrm{NH}, \mathrm{Et}_{2} \mathrm{O}$, rt; (b) $\mathrm{MsCl}, \mathrm{Et}_{3} \mathrm{~N}, \mathrm{CH}_{2} \mathrm{Cl}_{2}, 0^{\circ} \mathrm{C}$; (c) $\mathrm{K}_{2} \mathrm{CO}_{3}, \mathrm{DMF}$, (high dilution), rt.

Aryliodides 10 and 11 were prepared from 1,2-diiodobenzene and propargyl alcohol or homopropargyl alcohol under Sonogashira conditions. ${ }^{14}$ Coupling of these enynes with enantiopure $N$-tosyl-protected propargylglycine methyl ester ${ }^{15}(R)-9$ proved to be straightforward leading to the acyclic enediynes $(R)-13$ and $(R)-14$ in $89 \%$ and $71 \%$ yield, respectively. ${ }^{16}$ Reaction with methanesulfonyl chloride $(\mathrm{MsCl})$ afforded the corresponding mesylates $\mathbf{1 5}$ and 16, setting the stage for base-induced cyclisation reactions. Treatment of highly diluted solutions $(6 \mathrm{mM})$ of these mesylates in DMF with potassium carbonate ( 5 equiv.) resulted in a clean conversion of the starting materials into products within $3 \mathrm{~h}$ according to TLC. In case of $n=1$, the desired 10-membered cyclic enediyne 4 could be isolated as a crystalline solid. Its 11 -membered homologue, however, could not be prepared using the latter reaction since elimination rather than ring closure took place, and the linear dienediyne $\mathbf{1 7}$ was produced instead. Interestingly, neither $\mathbf{4}$ nor $\mathbf{1 7}$ showed optical activity in the polarimeter as opposed to their respective parent compounds.

The racemic nature of product $\mathbf{4}$ was confirmed by its crystal structure (see Fig. 2), showing both enantiomers in the unit cell. Supposedly, the racemisation takes place after cyclisation during which the sulfonamide proton is substituted. Due to the lack of a more acidic $N H$, the $\alpha$-proton of the now cyclic structure is prone to deprotonation by a relatively mild base such as potassium carbonate. Following this reasoning, the racemisation of $\mathbf{1 7}$ can best be explained by assuming initial formation of the desired 11membered ring, followed by racemisation and finally ring strainpromoted eliminative ring fission ${ }^{17}$ to give the acyclic expanded conjugated system.

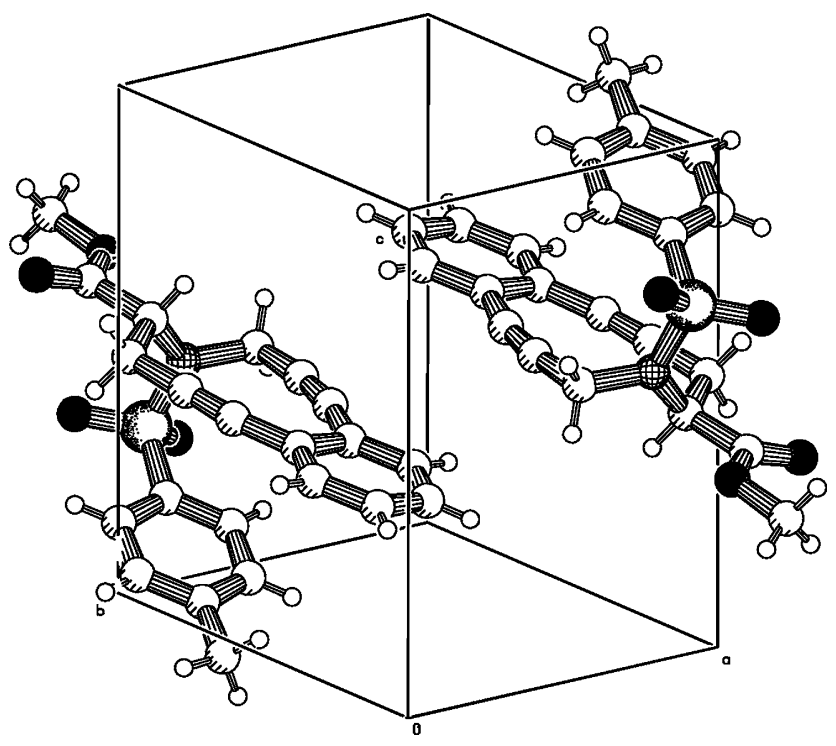

Fig. 2 Both enantiomers of enediyne 4 are present in its unit cell. ${ }^{18}$

Clearly, the racemisation and elimination problems in the cyclisation step called for conditions as gentle as possible to promote this transformation in the desired sense. ${ }^{19}$ The Mitsunobu reaction $^{20}$ has been recognised as a mild and efficient way to $N$-alkylate sulfonamides or sulfonamide-protected amino acids, especially when applied for intramolecular bond formation. ${ }^{21}$ This strategy has also been applied by Du et al. in the synthesis of the cyclic enediyne-containing amino acids 3. ${ }^{9}$ Following this concept, acyclic enediynes 13 and 14 were treated with DEAD and $\mathrm{PPh}_{3}$ under high dilution $(\sim 5 \mathrm{mM})$ in THF (Scheme 3$)$. To our dismay, the outcome very much resembled the mesylate displacement approach. Starting from $(R)-\mathbf{1 3}(>98 \% e e)$, the 10-membered enediyne $(R)-4$ was obtained with a substantially diminished enantiomeric excess $(76 \%$ ee $)$. Surprisingly, even under the mild conditions applied, elimination and also partial racemisation took place with homopropargylic enynol $(R)-\mathbf{1 4}(>98 \% e e)$. The $e e$ of the elimination product $(R)-\mathbf{1 7}$ was determined to be as low as $42 \%$. It has to be assumed that racemisation proceeds 


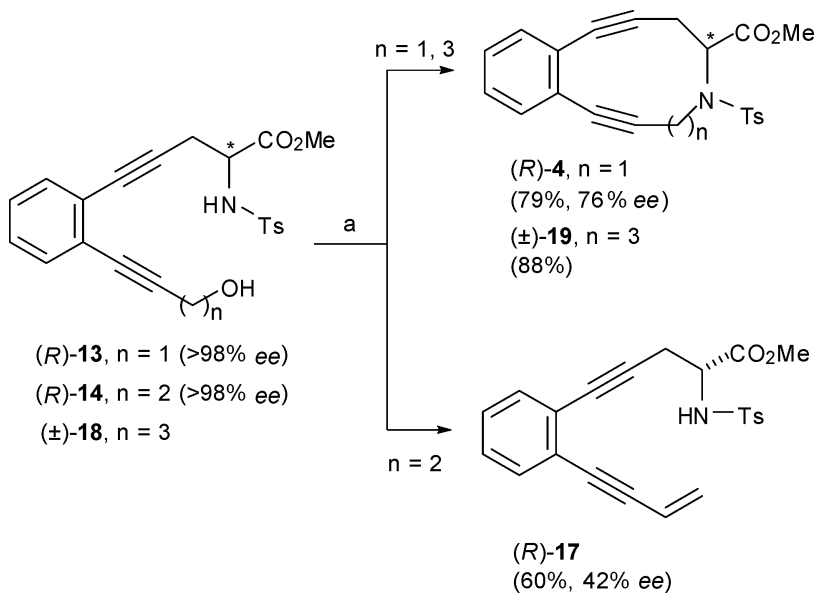

Scheme 3 Synthesis via Mitsunobu-type reaction. Reagents and conditions: (a) $\mathrm{PPh}_{3}, \mathrm{DEAD}, \mathrm{THF}$ (high dilution), rt.

via the cyclic enediyne as in the mesylate approach. These observations, once more, clearly show the acidic nature of the $\alpha$ proton of the cyclic amino acids. Finally, the racemic homologue $( \pm)-18$ was cyclised under identical conditions, furnishing the corresponding cyclic 12-membered enediyne 19 in a good yield of $88 \%$. These results emphasise the more general applicability of the Mitsunobu reaction for preparing cyclic enediynes, although the previously unaddressed ${ }^{9}$ issue of racemisation could not be fully circumvented.

Along the same line, we set out to assemble an analogous series of non-benzofused enediynes (Scheme 4). Synthesis of the cyclisation substrates from racemic propargylglycine ( \pm )-9

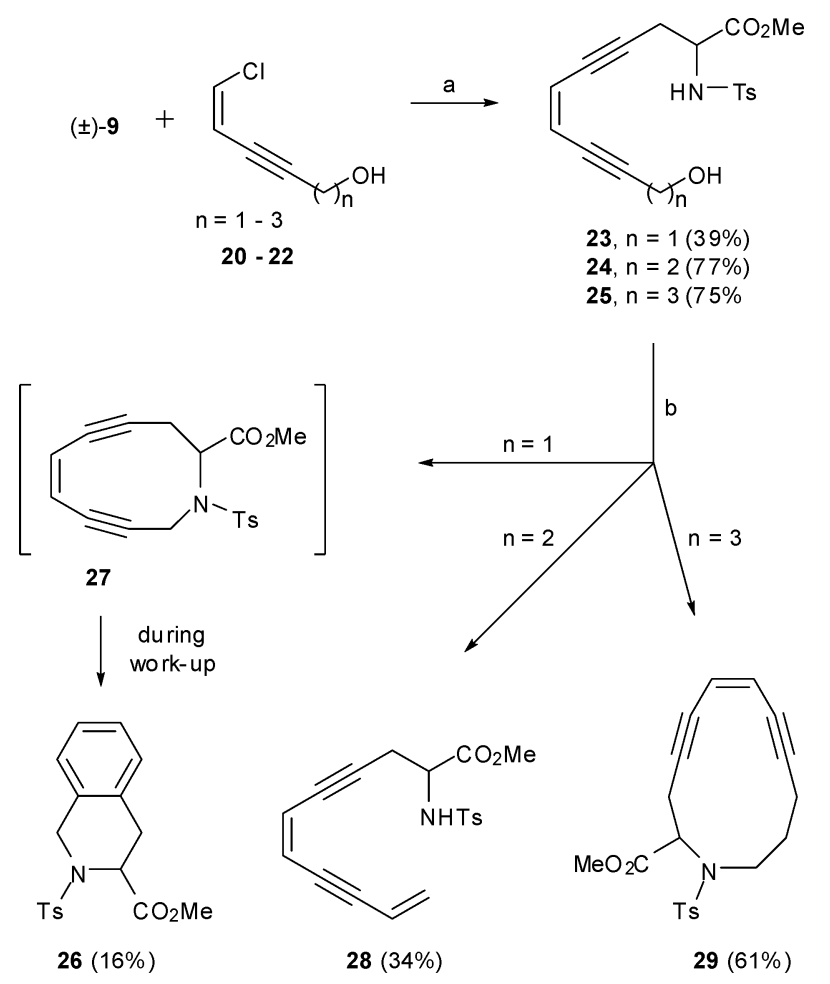

Scheme 4 Synthesis of olefinic cyclic enediynes. Reagents and conditions: (a) Haloenynol (20, 21, or 22), $\mathrm{PdCl}_{2}\left(\mathrm{PPh}_{3}\right)_{2}$ (cat.), $\mathrm{CuI}$ (cat.), $n-\mathrm{BuNH}_{2}$, $\mathrm{Et}_{2} \mathrm{O}$, rt; (b) $\mathrm{PPh}_{3}$, DEAD, THF (high dilution), rt. and haloenynols 20-22 ${ }^{14}$ proceeded via Sonogashira coupling as anticipated, giving rise to enediynols 23-25. Subjection of precursor 23 to Mitsunobu conditions led to the consumption of starting material with concomitant appearance of a single new spot on TLC which, however, had disappeared after work-up. No enediyne could be isolated, instead the tetrahydroisoquinoline derivative $\mathbf{2 6}$ was obtained, showing a different retention factor on TLC.

Supposedly, the enediyne $\mathbf{2 7}$ had been formed, but underwent Bergman cyclisation at ambient temperature within 30 minutes under work-up conditions. In contrast to this behaviour, its benzofused counterpart $\mathbf{4}$ was stable in crystalline form at room temperature for months and could be kept in a chloroform solution for several days without deterioration. ${ }^{22}$ The higher homologues reacted like their benzofused counterparts: the homopropargylic alcohol $\mathbf{2 4}$ led to the elimination product $\mathbf{2 8}$ in 34\%, while $\mathbf{2 5}$ was transformed into the $12-$ membered cycle 29 in a reasonable yield $(61 \%)$.

In order to gain access to the thus far elusive 11-membered cyclic enediynes, it was decided to start from protected $(S)$ homopropargylglycine ${ }^{15}$ 30. In this strategy, $\beta$-elimination of the amine is no longer possible in the cyclisation step. Acyclic enediynes 31 and $\mathbf{3 2}$ were readily formed by Sonogashira couplings. Their intramolecular condensation under high dilution Mitsunobu conditions furnished the cyclic 11-membered enediynes 33 and 34 in 70\% and 80\% yield, respectively, with both products displaying optical activity (Scheme 5). ${ }^{23}$

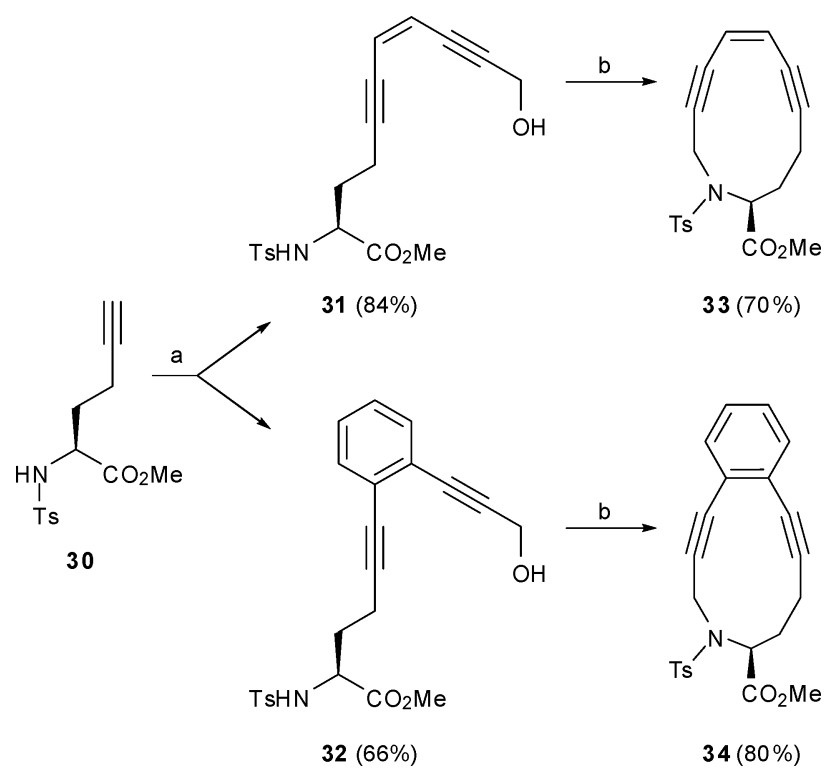

Scheme 5 Assembly of 11-membered cyclic enediynes. Reagents and conditions: (a) Haloenynol (10 or 20), $\mathrm{PdCl}_{2}\left(\mathrm{PPh}_{3}\right)_{2}, \mathrm{CuI}$ (cat.), $n$ - $\mathrm{BuNH}_{2}$, $\mathrm{Et}_{2} \mathrm{O}$, rt; (b) $\mathrm{PPh}_{3}, \mathrm{DEAD}$, THF (high dilution), rt.

Crystals suitable for X-ray structural analysis could be obtained from compounds 4, 19, 29, and 34 (Fig. 3). ${ }^{24}$

A number of parameters are relevant with respect to the rate of the Bergman cyclisation of cyclic enediynes: It has been proposed that the distance between the acetylene termini (c- $\mathrm{d}$ distance, viz. Fig. 1) should be in the range of 2.9-3.4 $\AA$ in order for the reaction to proceed at physiological temperatures. ${ }^{25}$ More recent studies attribute a greater role to the strain difference between 


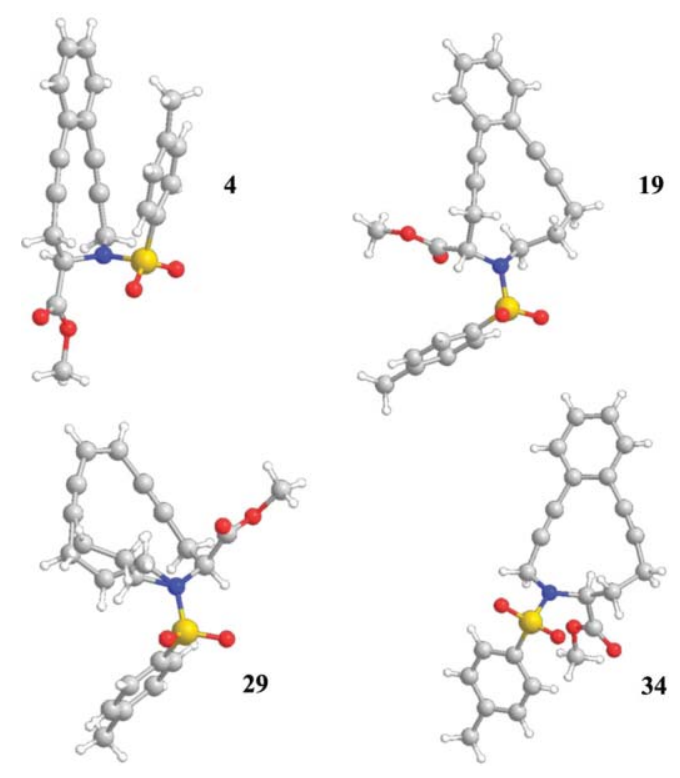

Fig. 3 X-ray crystal structures of cyclic enediynes 4, 19, 29, and 34.

the ground state and the transition state of the reaction. ${ }^{26}$ The electronic influences on the BC are probably the least studied, but it is known that benzannulation of the olefinic portion of cyclic enediynes slows down the cyclisation process. ${ }^{27}$ Furthermore, for some cyclic, benzannulated enediynes the rate-determining step is the quenching of the benzenoid diradical, and the reaction rate therefore can be dependent on the concentration of the radical trap. $^{28}$

With our series of enediynes in hand we set out to study their behaviour in the BC. Enediynes 4, 19, 29, 33, and 34 were dissolved in deuterated DMSO $(\mathrm{c}=0.1 \mathrm{M}), 1,4$-cyclohexadiene (CHD, 2 equiv.) and an internal standard were added, and the samples were sealed under an argon atmosphere before being subjected to elevated temperatures. The formation of product and the consumption of starting material were monitored by ${ }^{1} \mathrm{H}-\mathrm{NMR}$. Table 1 summarises the results.
The 10-membered olefinic enediyne 27 (entry 1) underwent cycloaromatisation spontaneously (Scheme 4). Its benzofused analogue 4 (entry 2) is the only structure with a confirmed c-d distance within the "reactive window" of 2.9-3.4 $\AA$, and it displayed a half-life of $59 \mathrm{~min}$ at $80{ }^{\circ} \mathrm{C}$ under the applied conditions. For the same compound, Du et al..$^{9}$ reported a half-life of $9.5 \mathrm{~h}$ at $55^{\circ} \mathrm{C}$ under somewhat different conditions $\left(\mathrm{c}=10^{-4} \mathrm{M}\right.$ in DMF, 100 equiv. CHD). ${ }^{29}$ Significantly higher temperatures and reaction times were required to induce $\mathrm{BC}$ of the 11-membered rings (entries 3-7), which followed our expectations. From the available crystal structure data of $\mathbf{3 4}$ it is apparent that its $\mathrm{c}-\mathrm{d}$ distance is well outside the proposed reactive range of 2.9$3.4 \AA$. It is therefore safe to assume that this is also true for its olefinic counterpart 33. Indeed, only a trace amount of the cyclised product was detected $\left({ }^{1} \mathrm{H}-\mathrm{NMR}\right)$ after having subjected 33 to temperatures of $80{ }^{\circ} \mathrm{C}$ for $24 \mathrm{~h}$. Increasing the temperature to $90{ }^{\circ} \mathrm{C}$ caused the $\mathrm{BC}$ to proceed with a half-life of $26 \mathrm{~h}$. Even higher temperatures were needed for benzene-fused 34 to aromatise efficiently: after $24 \mathrm{~h}$ at $90^{\circ} \mathrm{C}$ only small amounts of the corresponding product could be detected. Finally, at $120^{\circ} \mathrm{C}$ a halflife of $175 \mathrm{~h}$ was measured (entry 7). Both 12-membered species 19 and 29 with c-d distances of $3.77 \AA$ and $3.88 \AA$, respectively, proved to be thermally stable at a temperature of $90{ }^{\circ} \mathrm{C}$ as anticipated. Upon subjecting samples to a temperature of $120{ }^{\circ} \mathrm{C}$, a trace amount of the cyclised 29 could be detected after $24 \mathrm{~h}$ while 19 remained unchanged (entries 9 and 10).

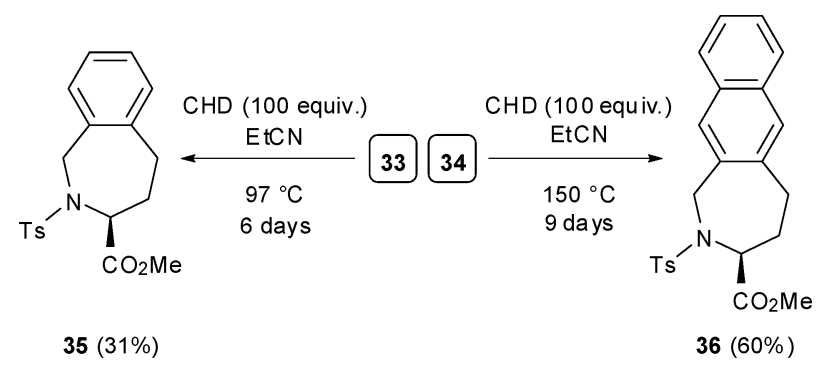

Scheme 6 Cycloaromatisation of 11-membered enediynes 33 and $\mathbf{3 4}$.

Table 1 Half-life determination of cyclic enediynes

$\Delta$

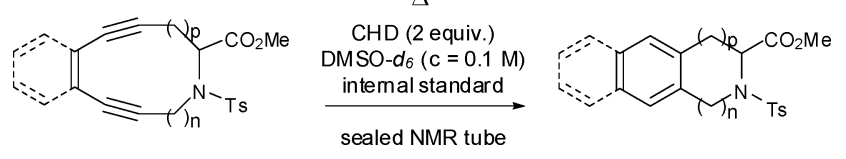

\begin{tabular}{|c|c|c|c|c|c|c|c|}
\hline Entry & Enediyne & Benzo-fused & $\mathrm{n}, \mathrm{p}$ & Ring size & $\mathrm{c}-\mathrm{d}(\AA)^{a}$ & $\mathrm{~T}\left({ }^{\circ} \mathrm{C}\right)$ & $t_{1 / 2}$ \\
\hline 1 & 27 & No & 1,1 & 10 & n.d. & $\mathrm{rt}-30^{b}$ & $<30 \mathrm{~min}$ \\
\hline 2 & 4 & Yes & - & - & 3.23 & 80 & $59 \mathrm{~min}$ \\
\hline 4 & - & - & - & - & - & 90 & $26 \mathrm{~h}$ \\
\hline 5 & $34^{d}$ & Yes & - & - & 3.76 & 80 & Stable $e^{e}$ \\
\hline 6 & - & - & - & - & - & 90 & Trace $^{c}$ \\
\hline 7 & - & - & - & - & - & 120 & $175 \mathrm{~h}$ \\
\hline 10 & 19 & Yes & - & - & 3.77 & 120 & Stable \\
\hline
\end{tabular}

${ }^{a}$ Obtained by crystal structure elucidation. ${ }^{b}$ Compound 27 cyclised during the work-up procedure. ${ }^{c} \mathrm{~A}$ small amount of the aromatisation product was observed by ${ }^{1} \mathrm{H}$-NMR after $24 \mathrm{~h}$ at the indicated temperature. ${ }^{d} \mathrm{c}=0.05 \mathrm{M} .{ }^{e}$ No product was observed by ${ }^{1} \mathrm{H}-\mathrm{NMR}$ after $24 \mathrm{~h}$ at the indicated temperature. 
In order to fully characterise the novel aromatisation products of $\mathbf{3 3}$ and $\mathbf{3 4},{ }^{30}$ both enediynes were heated in the presence of 100 equivalents of 1,4-cyclohexadiene in proprionitrile (Scheme 6). After 6 days at reflux temperature $\left(97{ }^{\circ} \mathrm{C}\right)$, enediyne $\mathbf{3 3}$ had been consumed completely and the tetrahydrobenzazepine 35 was isolated in a mediocre yield of $31 \%$. Similarly, the benzene-fused derivative $\mathbf{3 4}$ was converted into the tetrahydronaphthoazepine $\mathbf{3 6}$ in a yield of $60 \%$ upon heating at $150{ }^{\circ} \mathrm{C}$ for 9 days in a sealed tube.

\section{Conclusions}

In summary, the synthesis of a series of 10-, 11-, and 12membered cyclic enediyne-containing amino acids has been described, proceeding via readily available acetylene-containing amino acid building blocks. During the cyclisation into the targeted enediyne structures, in several instances an unexpected (partial) racemisation took place, even under virtually neutral Mitsunobu conditions. While the synthesis of 11-membered ring systems failed starting from propargylglycine due to $\beta$-elimination after ring closure, isomeric 11-membered ring enediynes could be successfully synthesized starting from homopropargylglycine.

Half-life determination experiments of the cylic enediynes showed that, in line with previous studies, all benzannulated enediynes reacted significantly slower than their unsubstituted counterparts. Moreover, it is evident that ring strain plays a major role: An increase in ring size goes along with a distinct decrease of the rate of cycloaromatisation, e.g. the discrepance in reactivity between 11-membered cycle 34 and 12-membered cycle 19, both showing almost equal $\mathrm{c}-\mathrm{d}$ distances in the solid state, can best be explained by the higher strain in the smaller ring.

Of the enediynes presented in this study, the 10-membered benzannulated system $\mathbf{4}$ has the highest potential utility: it is stable at room temperature but can be activated at modestly elevated temperatures. Investigations concerning further structural optimisation and conjugation of $\mathbf{4}$ with peptides and targeting devices are currently ongoing.

\section{Experimental}

\section{General information}

Solvents were distilled from appropriate drying agents prior to use and stored under nitrogen. Enantiopure propargyl- and homopropargylglycine were purchased from Chiralix B.V. All other chemicals were purchased from Sigma-Aldrich or Acros and used as received, unless stated otherwise. Reactions were carried out under an inert atmosphere of dry nitrogen or argon. Reactions were followed and $\mathrm{R}_{f}$ values are obtained using thin layer chromatography (TLC) on silica gel-coated plates (Merck $60 \mathrm{~F}_{254}$ ) with the indicated solvent mixture. IR spectra were recorded on an ATI Mattson Genesis Series FTIR spectrometer, or a Bruker Tensor 27 FTIR spectrometer. NMR spectra were recorded on a Bruker DPX $200(200 \mathrm{MHz})$, a Bruker DMX 300 $(300 \mathrm{MHz})$, and a Varian Inova $400(400 \mathrm{MHz})$. Chemical shifts are given in ppm with respect to tetramethylsilane (TMS) as internal standard. Coupling constants are reported as $J$-values in Hz. Flash chromatography was carried out using ACROS silica gel (0.035$0.070 \mathrm{~mm}, 6 \mathrm{~nm}$ pore diameter). Optical rotations were determined with a Perkin Elmer 241 polarimeter; concentrations $(c)$ are given in $\mathrm{g} / 100 \mathrm{~mL}$. The ee values were obtained by chiral HPLC on a Shimadzu LC-2010C apparatus equipped with a Daicell AD$\mathrm{H}$ column (eluent: hexane/2-propanol). High resolution mass spectra were recorded on a MAT900 (EI, CI and ESI).

\section{3-(2-Iodophenyl)prop-2-yn-1-ol (10)}

1,2-Diiodobenzene (1.010 g, $3.062 \mathrm{mmol})$ was dissolved in $\mathrm{Et}_{2} \mathrm{O}$ $(10 \mathrm{~mL}) . \mathrm{Pd}\left(\mathrm{PPh}_{3}\right)_{4}(140 \mathrm{mg}, 0.121 \mathrm{mmol})$ and $\mathrm{CuI}(53 \mathrm{mg}$, $0.280 \mathrm{mmol}$ ) were added to the stirred solution, followed by $n$ $\mathrm{BuNH}_{2}(1.5 \mathrm{~mL}, 15.2 \mathrm{mmol})$. Once a clear, homogeneous solution had been formed, prop-2-yn-1-ol $(0.175 \mathrm{~mL}, 3.006 \mathrm{mmol})$ was added via syringe and stirring was continued for $6 \mathrm{~h}$. One aliquot of a saturated solution of $\mathrm{NH}_{4} \mathrm{Cl}$ was poured into the reaction flask, the phases were separated, and the aqueous layer was extracted with EtOAc $(3 \times 5 \mathrm{~mL})$. The combined organic layers were washed with brine, dried over $\mathrm{mgSO}_{4}$, and concentrated in vacuo. The crude product was purified by flash chromatography (EtOAc/heptane, 2:7) yielding $\mathbf{1 0}$ as a yellowish oil that solidified on cooling (401 mg, $1.554 \mathrm{mmol}, 52 \%$ ). The characterisation data were consistent with those in ref. 14a.

\section{4-(2-Iodophenyl)but-3-yn-1-ol (11)}

The title compound was prepared following the same procedure as described for $\mathbf{1 0}$ starting from 1,2-diiodobenzene $(669 \mathrm{mg}$, $2.027 \mathrm{mmol})$ in $\mathrm{Et}_{2} \mathrm{O}(10 \mathrm{~mL}), \mathrm{PdCl}_{2}(\mathrm{PPh} 3)_{2}(70 \mathrm{mg}, 0.010 \mathrm{mmol})$, $\mathrm{CuI}(40 \mathrm{mg}, 0.210 \mathrm{mmol}), \mathrm{Et}_{2} \mathrm{NH}(1.05 \mathrm{~mL}, 10 \mathrm{mmol})$, and but-3-yn-1-ol $(0.190 \mathrm{~mL}, 2.510 \mathrm{mmol})$. Flash chromatography (EtOAc/heptane, 1:10 $\rightarrow$ 1:3) furnished $\mathbf{1 1}$ as a light brown oil (318 mg, $1.169 \mathrm{mmol}, 58 \%)$. The characterisation data were consistent with those in ref. $14 \mathrm{~b}$.

\section{5-(2-Iodophenyl)pent-4-yn-1-ol (12)}

The title compound was prepared following the same procedure as described for 10 by letting react a solution of 1,2-diiodobenzene $(2.34 \mathrm{~g}, 7.09 \mathrm{mmol})$ in $\mathrm{Et}_{2} \mathrm{O}(20 \mathrm{~mL})$ with $\mathrm{Pd}\left(\mathrm{PPh}_{3}\right)_{4}(218 \mathrm{mg}$, $0.188 \mathrm{mmol}), \mathrm{CuI}(61 \mathrm{mg}, 0.320 \mathrm{mmol}), n-\mathrm{BuNH}_{2}(3.8 \mathrm{~mL}$, $38.4 \mathrm{mmol})$, and pent-4-yn-1-ol $(0.66 \mathrm{~mL}, 7.09 \mathrm{mmol})$ over a period of $12 \mathrm{~h}$. Work-up and purification by flash chromatography (EtOAc/heptane, 1:10 $\rightarrow$ 2:3) gave $\mathbf{1 2}$ as a yellow oil (1.081 g, $3.78 \mathrm{mmol}, 53 \%$ ). The characterisation data were consistent with those in ref. 14a.

\section{(R)-5-[2-(3-Hydroxy-prop-1-ynyl)-phenyl]-2-(toluene-4- sulfonylamino)-pent-4-ynoic acid methyl ester (13)}

A stirred solution of 4-(2-iodophenyl)prop-3-yn-1-ol (10) (335 mg, $1.298 \mathrm{mmol})$ in $\mathrm{Et}_{2} \mathrm{O}(15 \mathrm{~mL})$ was treated with $\mathrm{PdCl}_{2}\left(\mathrm{PPh}_{3}\right)_{2}$ (40 mg, $0.057 \mathrm{mmol}$ ), $\mathrm{CuI}(22 \mathrm{mg}, 0.116 \mathrm{mmol})$, and $\mathrm{Et}_{2} \mathrm{NH}$ $(0.57 \mathrm{~mL}, 5.5 \mathrm{mmol})$. Stirring was continued until a clear, homogeneous solution had been formed and propargylglycine ${ }^{15}$ (R)-9 (309 mg, $1.098 \mathrm{mmol}$ ) was added. After $4 \mathrm{~h}$ at ambient temperature, the reaction mixture was poured into an aliquot of a saturated solution of $\mathrm{NH}_{4} \mathrm{Cl}$, the phases were separated and the aqueous layer was extracted with EtOAc $(33 \times 8 \mathrm{~mL})$. The combined organic layers were washed with brine, dried over $\mathrm{mgSO}_{4}$, and all volatiles were removed in vacuo. Purification 
by flash chromatography (EtOAc/heptane, 2:3) provided $\mathbf{1 3}$ as a yellowish oil (401 mg, $0.975 \mathrm{mmol}, 89 \%$ ). $\mathrm{R}_{f} 0.48$ (EtOAc/heptane, $1: 1) ; e e=98.5 \%$; $v_{\max }$ (neat) $3483,3276,2952,1737,1635,1592$, 1477, 1439; ${ }^{1} \mathrm{H}-\mathrm{NMR}$ and ${ }^{13} \mathrm{C}-\mathrm{NMR}$ spectra were consistent with those published in ref. 9; HRMS (EI) calcd. for $\mathrm{C}_{22} \mathrm{H}_{21} \mathrm{NO}_{5} \mathrm{~S}\left(\mathrm{M}^{+}\right)$ 411.1140, found 411.1136 .

\section{4-Tosyl-1,2,7,8-tetradehydro-3,4,5,6-tetrahydro-4-benzazecine-5- carboxylic acid methyl ester (4)}

i) via mesylate displacement. To a cooled solution $\left(0{ }^{\circ} \mathrm{C}\right)$ of alcohol $(R)-13(338 \mathrm{mg}, 0.821 \mathrm{mmol})$ in $\mathrm{CH}_{2} \mathrm{Cl}_{2}(15 \mathrm{~mL})$, $\mathrm{MsCl}(0.13 \mathrm{~mL}, 1.67 \mathrm{mmol})$ and $\mathrm{Et}_{3} \mathrm{~N}(0.23 \mathrm{~mL}, 1.66 \mathrm{mmol})$ were added. The reaction mixture was allowed to reach room temperature and was stirred for $4 \mathrm{~h}$ after which it was poured into $\mathrm{CH}_{2} \mathrm{Cl}_{2}$ /water $(80 \mathrm{~mL}, 1: 1)$. The layers were separated, and the organic layer was washed with water $(23 \times 40 \mathrm{~mL})$, dried over $\mathrm{mgSO}_{4}$ and concentrated in vacuo. Purification by flash chromatography (EtOAc/heptane, 2:3) afforded the mesylate $(R)-15$ as a yellow oil (347 $\mathrm{mg}, 0.709 \mathrm{mmol}, 86 \%) . \mathrm{R}_{f} 0.22$ (EtOAc/heptane, 2:3); $\delta_{\mathrm{H}}\left(300 \mathrm{MHz}, \mathrm{CDCl}_{3}\right) 7.75(2 \mathrm{H}, \mathrm{d}, J=$ 8.2 Hz), 7.46-7.40 (1 H, m), 7.36-7.22 (5 H, m), $5.68(1 \mathrm{H}, \mathrm{d}, J=$ $8.4 \mathrm{~Hz}), 5.22(2 \mathrm{H}, \mathrm{dd}, J=15.9,17.4 \mathrm{~Hz}), 4.18-4.13(1 \mathrm{H}, \mathrm{m}), 3.62$ $(3 \mathrm{H}, \mathrm{s}), 2.97(2 \mathrm{H}, \mathrm{d}, J=4.8 \mathrm{~Hz}), 2.38(3 \mathrm{H}, \mathrm{s})$.

A dilute solution of the mesylate $(R)-15(334 \mathrm{mg}, 0.682 \mathrm{mmol})$ in DMF $(115 \mathrm{~mL} ; \mathrm{c}=6 \mathrm{mM})$ was treated with $\mathrm{K}_{2} \mathrm{CO}_{3}(470 \mathrm{mg}$, $3.40 \mathrm{mmol}$ ) and stirred for $2 \mathrm{~h}$ at room temperature. The mixture was poured into EtOAc/water $(600 \mathrm{~mL}, 1: 1)$, and the layers were separated. The organic layer was washed with water $(33 \times 300 \mathrm{~mL})$, dried over $\mathrm{mgSO}_{4}$, and concentrated in vacuo at room temperature. After flash chromatography (EtOAc/heptane, 1:4), enediyne ( \pm )-4 was obtained as a white solid $201 \mathrm{mg}, 0.511 \mathrm{~mol}, 75 \%$ ). Crystals suitable for X-ray analysis could be grown from EtOAc/heptane. $[\alpha]_{\mathrm{D}}^{22}=0^{\circ}\left(c 0.5, \mathrm{CH}_{2} \mathrm{Cl}_{2}\right)$.

ii) via Mitsunobu reaction. Triphenylphosphine $(262 \mathrm{mg}$, $0.999 \mathrm{mmol})$ was dissolved in a dilute solution $(\mathrm{c}=5 \mathrm{mM})$ of alcohol $(R)-13(207 \mathrm{mg}, 0.503 \mathrm{mmol})$ in THF $(100 \mathrm{~mL})$. DEAD ( $40 \%$ in toluene; $0.150 \mathrm{~mL}, 0.953 \mathrm{mmol}$ ) was added, and the reaction mixture was stirred for $80 \mathrm{~min}$ at ambient temperature followed by removal of all volatiles in vacuo at room temperature. Flash chromatography (EtOAc/heptane, 1:10 $\rightarrow$ 1:3) afforded $(R)-4$ as a white solid (156 mg, $0.396 \mathrm{mmol}, 79 \%)$. $e e=73 \%$.

General characterisation data. $\quad \mathrm{R}_{f} 0.19$ (EtOAc/heptane, 1:4); $v_{\max }$ (neat) $2958,1735,1593,1459,1433 ;{ }^{1} \mathrm{H}-\mathrm{NMR}$ and ${ }^{13} \mathrm{C}-\mathrm{NMR}$ spectra were consistent with those published in ref.9; HRMS (EI) calcd. for $\mathrm{C}_{22} \mathrm{H}_{19} \mathrm{NO}_{4} \mathrm{~S}\left(\mathrm{M}^{+}\right)$393.1035, found 393.1038.

\section{(R)-5-[2-(4-Hydroxy-but-1-ynyl)phenyl]-2-(toluene-4- sulfonylamino)-pent-4-ynoic acid methyl ester (14)}

The title compound was synthesised following the same procedure as described for $\mathbf{1 3}$ by allowing to react 4-(2-iodophenyl)but3-yn-1-ol (11) in $\mathrm{Et}_{2} \mathrm{O}(15 \mathrm{~mL})$ with $\mathrm{PdCl}_{2}\left(\mathrm{PPh}_{3}\right)_{2}(18 \mathrm{mg}$, $0.025 \mathrm{mmol}), \mathrm{CuI}(10 \mathrm{mg}, 0.052 \mathrm{mmol}), \mathrm{Et}_{2} \mathrm{NH}(0.26 \mathrm{~mL}$, $2.5 \mathrm{mmol})$, and propargylglycine $(R)-9$ over a period of $12 \mathrm{~h}$. Workup and purification by flash chromatography (EtOAc/heptane, 2:3) afforded $\mathbf{1 4}$ as a light yellow oil (151 $\mathrm{mg}, 0.355 \mathrm{mmol}, 71 \%$ ). $\mathrm{R}_{f} 0.15$ (EtOAc/heptane, 2:3); ee $>99 \%$; $v_{\max }$ (neat) 3495, 3266, $2955,1736,1584,1473,1438 ; \delta_{\mathrm{H}}\left(300 \mathrm{MHz}, \mathrm{CDCl}_{3}\right) 7.74(2 \mathrm{H}$, d, $J=8.4 \mathrm{~Hz}), 7.38-7.35(1 \mathrm{H}, \mathrm{m}), 7.29-7.14(5 \mathrm{H}, \mathrm{m}), 6.12$ ( $1 \mathrm{H}, \mathrm{d}, J=8.7 \mathrm{~Hz}), 4.20-4.14(1 \mathrm{H}, \mathrm{m}), 3.89-3.82(2 \mathrm{H}, \mathrm{m})$, $3.61(3 \mathrm{H}, \mathrm{s}), 2.98(2 \mathrm{H}, \mathrm{dd}, J=5.0,3.4 \mathrm{~Hz}), 2.86(2 \mathrm{H}, \mathrm{dt}, J=$ $5.8,2.7 \mathrm{~Hz}), 2.55(1 \mathrm{H}, \mathrm{t}, J=6.3 \mathrm{~Hz}), 2.34(3 \mathrm{H}, \mathrm{s}) ; \delta_{\mathrm{C}}(75 \mathrm{MHz}$, $\left.\mathrm{CHCl}_{3}\right)$ 169.9, 143.3, 136.8, 131.8, 131.6, 129.4, 127.7, 127.3, 126.9, $125.8,125.0,91.1,86.5,83.0,81.3,60.9,54.3,52.9,25.2,24.0$, 21.7; HRMS (EI) calcd. for $\mathrm{C}_{23} \mathrm{H}_{23} \mathrm{NO}_{5} \mathrm{~S}\left(\mathrm{M}^{+}\right)$425.1297, found 425.1309 .

\section{5-(2-But-3-en-1-ynyl-phenyl)-2-(toluene-4-sulfonylamino)-pent-4- ynoic acid methyl ester (17)}

i) via mesylate displacement. Whilst stirring, a solution of alcohol $(R)-14$ (460 $\mathrm{mg}, 1.081 \mathrm{mmol})$ in $\mathrm{CH}_{2} \mathrm{Cl}_{2}(20 \mathrm{~mL})$ at $0{ }^{\circ} \mathrm{C}$ was treated with $\mathrm{MsCl}(0.17 \mathrm{~mL}, 2.18 \mathrm{mmol})$ and $\mathrm{Et}_{3} \mathrm{~N}$ $(0.30 \mathrm{~mL}, 2.16 \mathrm{mmol})$. The mixture was allowed to come to room temperature and stirred for additional $3 \mathrm{~h}$ after which time it was poured into $\mathrm{CH}_{2} \mathrm{Cl}_{2}$ /water $(100 \mathrm{~mL}, 1: 1)$. The layers were separated, and the organic layer was washed with water $(23 \times 50 \mathrm{~mL})$, dried over $\mathrm{mgSO}_{4}$ and concentrated in vacuo. Purification by flash chromatography (EtOAc/heptane, 2:3) produced mesylate $(R)-\mathbf{1 6}$ as a yellow oil $(495 \mathrm{mg}, 0.983 \mathrm{mmol}$, 93\%). $\mathrm{R}_{f} 0.15$ (EtOAc/heptane, 2:3); $\delta_{\mathrm{H}}\left(300 \mathrm{MHz}, \mathrm{CDCl}_{3}\right) 7.73$ ( $2 \mathrm{H}, \mathrm{d}, J=8.4 \mathrm{~Hz}), 7.40-7.37(1 \mathrm{H}, \mathrm{m}), 7.31-7.16(5 \mathrm{H}, \mathrm{m}), 5.60$ $(1 \mathrm{H}, \mathrm{d}, J=9.0 \mathrm{~Hz}), 4.46(2 \mathrm{H}, \mathrm{t}, J=6.6 \mathrm{~Hz}), 4.20-4.13(1 \mathrm{H}, \mathrm{m})$, $3.62(3 \mathrm{H}, \mathrm{s}), 3.08(3 \mathrm{H}, \mathrm{s}), 3.02(2 \mathrm{H}, \mathrm{t}, J=6.6 \mathrm{~Hz}), 2.93(2 \mathrm{H}, \mathrm{t}$, $J=4.5 \mathrm{~Hz}), 2.38(3 \mathrm{H}, \mathrm{s})$.

To a dilute solution of the mesylate $(R)-\mathbf{1 6}(480 \mathrm{mg}, 0.953 \mathrm{mmol})$ in DMF $(160 \mathrm{~mL} ; \mathrm{c}=6 \mathrm{mM})$ was added $\mathrm{K}_{2} \mathrm{CO}_{3}(658 \mathrm{mg}$, $4.77 \mathrm{mmol}$ ) and the mixture was stirred for $2 \mathrm{~h}$ at room temperature. The contents of the reaction vessel were poured into EtOAc/water (800 mL, 1:1), and the phases were separated. The organic layer was washed with water $(33 \times 400 \mathrm{~mL})$, dried over $\mathrm{mgSO}_{4}$, and concentrated in vacuo. After flash chromatography (EtOAc/heptane, 1:4), the title compound was obtained as a colourless oil $(295 \mathrm{mg}, 0.724 \mathrm{mmol}, 76 \%) \cdot[\alpha]^{22}{ }_{\mathrm{D}}=0^{\circ}(c \quad 0.5$, $\mathrm{CH}_{2} \mathrm{Cl}_{2}$ ).

ii) via Mitsunobu reaction. A stirred, dilute solution of alcohol $(R)-14(115 \mathrm{mg}, 0.270 \mathrm{mmol})$ in THF $(75 \mathrm{~mL} ; \mathrm{c}=4 \mathrm{mM})$ was treated with $\mathrm{PPh}_{3}(71 \mathrm{mg}, 0.271 \mathrm{mmol})$. As soon as it had been dissolved, DEAD (40\% in toluene; $0.043 \mathrm{~mL}, 0.273 \mathrm{mmol}$ ) was added via syringe and stirring was continued for $2 \mathrm{~h}$. The volatiles were removed in vacuo, and the crude product was subjected to flash chromatography (EtOAc/heptane, 1:10 $\rightarrow 1: 3$ ) yielding $(R)$ 17 as a slightly yellowish oil (66 mg, $0.162 \mathrm{mmol}, 60 \%)$. ee = $42 \%$.

General characterisation data. $\quad \mathrm{R}_{f} 0.14$ (EtOAc/heptane, 1:4); $v_{\max }$ (neat) $3270,2949,2915,1740,1593,1480,1442 ; \delta_{\mathrm{H}}(300 \mathrm{MHz}$, $\left.\mathrm{CDCl}_{3}\right) 7.75(2 \mathrm{H}, \mathrm{d}, J=8.4 \mathrm{~Hz}), 7.44-7.41(1 \mathrm{H}, \mathrm{m}), 7.35-7.19$ $(5 \mathrm{H}, \mathrm{m}), 6.13(1 \mathrm{H}, \mathrm{dd}, J=17.5,11.2 \mathrm{~Hz}), 5.80(1 \mathrm{H}, \mathrm{dd}, J=$ 17.6, 2.1 Hz), $5.60(1 \mathrm{H}, \mathrm{dd}, J=11.1,2.1 \mathrm{~Hz}), 5.56(1 \mathrm{H}, \mathrm{d}, J=$ $9.1 \mathrm{~Hz}), 4.22(1 \mathrm{H}$, ddd, $J=9.1,5.4,4.6 \mathrm{~Hz}), 3.62(3 \mathrm{H}, \mathrm{s}), 2.99$ (1 H, dd, 17, $4.6 \mathrm{~Hz}), 2.89(1 \mathrm{H}, \mathrm{dd}, 17 \mathrm{~Hz}, 5.4 \mathrm{~Hz}), 2.38(3 \mathrm{H}$, s); $\delta_{\mathrm{C}}\left(75 \mathrm{MHz}, \mathrm{CHCl}_{3}\right) 169.9,143.6,136.9,132.1,131.9,129.6$, 127.9 (2 C), 127.6, 127.1, 125.6, 124.9, 117.2, 92.0, 88.7, 86.9, 83.0, 54.5, 53.1, 25.5, 21.8; HRMS (EI) calcd. for $\mathrm{C}_{23} \mathrm{H}_{21} \mathrm{NO}_{4} \mathrm{~S}\left(\mathrm{M}^{+}\right)$ 407.1191, found 407.1193 . 


\section{5-[2-(5-Hydroxypent-1-ynyl)phenyl]-2-(toluene-4- sulfonylamino)pent-4-ynoic acid methyl ester (18)}

The title compound was synthesised analoguously to the preparation of 13. Thus, 5-(2-iodophenyl)pent-4-yn-1-ol (12) $(377 \mathrm{mg}$, $1.318 \mathrm{mmol})$ was stirred with $\mathrm{Pd}\left(\mathrm{PPh}_{3}\right)_{4}(81 \mathrm{mg}, 0.070 \mathrm{mmol})$, $\mathrm{CuI}(30 \mathrm{mg}, 0.158 \mathrm{mmol})$, and $\mathrm{Et}_{2} \mathrm{NH}(0.8 \mathrm{~mL}, 7.7 \mathrm{mmol})$ in $\mathrm{Et}_{2} \mathrm{O}(25 \mathrm{~mL})$ before propargylglycine $( \pm)-9(405 \mathrm{mg}, 1.440 \mathrm{mmol})$ was added, and stirring was continued over night. Work-up and purification by flash chromatography (EtOAc/heptane, 1:1) afforded 18 as an off-white solid (578 mg, $1.315 \mathrm{mmol}, 99 \%$ ). Crystals suitable for X-ray analysis could be grown from a $\mathrm{CHCl}_{3}$ solution top-layered with heptane. $\mathrm{R}_{f} 0.32$ (EtOAc/heptane, 1:1); $v_{\max }(\mathrm{KBr}) 3486,3118,2942,2228,1752 ; \delta_{\mathrm{H}}\left(300 \mathrm{MHz}, \mathrm{CDCl}_{3}\right)$ $7.75(2 \mathrm{H}, \mathrm{d}, J=8.3 \mathrm{~Hz}), 7.40-7.37(1 \mathrm{H}, \mathrm{m}), 7.30-7.16(5 \mathrm{H}$, $\mathrm{m}), 6.11(1 \mathrm{H}, \mathrm{d}, J=8.9 \mathrm{~Hz}), 4.18(1 \mathrm{H}, \mathrm{td}, J=9.0,5.2 \mathrm{~Hz})$, $3.89(1 \mathrm{H}, \mathrm{q}, J=5.8 \mathrm{~Hz}), 3.64(3 \mathrm{H}, \mathrm{s}), 2.98(1 \mathrm{H}, \mathrm{dd}, J=17.0$, $5.3 \mathrm{~Hz}), 2.90(1 \mathrm{H}, \mathrm{dd}, J=17.0,5.1 \mathrm{~Hz}), 2.67(1 \mathrm{H}, \mathrm{dt}, J=6.6$, $0.8 \mathrm{~Hz}), 2.34(3 \mathrm{H}, \mathrm{s}), 2.30(1 \mathrm{H}, \mathrm{t}, J=5.6 \mathrm{~Hz}), 1.96-1.87(2 \mathrm{H}$, $\mathrm{m}) ; \delta_{\mathrm{C}}\left(75 \mathrm{MHz}, \mathrm{CHCl}_{3}\right)$ 170.4, 143.6, 137.0, 132.1, 132.0, 128.0, 127.3, 127.2, 126.2, 124.9, 93.8, 86.5, 83.0, 80.1, 61.9, 54.3, 52.8, 31.1, 24.9, 21.5, 16.3; HRMS (CI) calcd. for $\mathrm{C}_{24} \mathrm{H}_{25} \mathrm{NO}_{5} \mathrm{~S}\left(\mathrm{M}^{+}\right)$ 439.1453, found 439.1441 .

\section{5-Tosyl-1,2,9,10-tetradehydro-3,4,5,6,7,8-hexahydro-5- benzazacyclododecine-4-carboxylic acid methyl ester (19)}

Triphenylphosphine (87 mg, $1.094 \mathrm{mmol}$ ) was dissolved in a solution of enediynic alcohol 18 (401 $\mathrm{mg}, 0.912 \mathrm{mmol})$ in THF (110 $\mathrm{mL} ; \mathrm{c}=8 \mathrm{mM})$. DEAD was added $(40 \%$ in toluene; $0.500 \mathrm{~mL}, 1.091 \mathrm{mmol}$ ), and the reaction mixture was stirred for $30 \mathrm{~min}$. The volatiles were removed in vacuo and the crude product was subjected to flash chromatography (EtOAc/heptane, 1:3) to yield 19 as a colourless oil that solidified on standing (339 mg, $0.804 \mathrm{mmol}, 88 \%$ ). Crystals suitable for X-ray analysis could be grown by slow evaporation of a $\mathrm{CHCl}_{3}$ solution. $\mathrm{R}_{f} 0.58$ (EtOAc/heptane, 1:1); $v_{\max }(\mathrm{KBr}) 3442,3069,2951,2920 ; 2230$, $1752,1598,1484,1348 ; \delta_{\mathrm{H}}\left(400 \mathrm{MHz}, \mathrm{CDCl}_{3}\right) 7.68(2 \mathrm{H}, \mathrm{d}, J=$ $8.4 \mathrm{~Hz}), 7.33-7.25(4 \mathrm{H}, \mathrm{m}), 7.21-7.13(2 \mathrm{H}, \mathrm{m}), 4.88(1 \mathrm{H}, \mathrm{dd}$, $J=6.5,2.4 \mathrm{~Hz}), 4.10(1 \mathrm{H}, \mathrm{ddd}, J=15.3,12.6 \mathrm{~Hz}, 4.1 \mathrm{~Hz}), 3.73$ ( $1 \mathrm{H}$, ddd, $J=15.0,12.3,4.9 \mathrm{~Hz}), 3.50(3 \mathrm{H}, \mathrm{s}), 3.36(1 \mathrm{H}, \mathrm{dd}$, $J=17.7,6.5 \mathrm{~Hz}), 2.83(1 \mathrm{H}, \mathrm{dd}, J=17.7,2.4 \mathrm{~Hz}), 2.56-2.42$ $(2 \mathrm{H}, \mathrm{m}), 2.40(3 \mathrm{H}, \mathrm{s}), 2.38-2.30(1 \mathrm{H}, \mathrm{m}), 2.08-1.97(1 \mathrm{H}, \mathrm{m}) ; \delta_{\mathrm{C}}$ $\left(100 \mathrm{MHz} \mathrm{CHCl}_{3}\right)$ 169.1, 143.4, 136.2, 131.1, 129.5, 127.9, 127.2, 126.8, 126.7, 94.5, 88.2, 82.8, 81.4, 57.8, 52.1, 45.8, 30.9, 23.9, 21.4, 17.0; HRMS (CI) calcd. for $\mathrm{C}_{24} \mathrm{H}_{23} \mathrm{NO}_{4} \mathrm{~S}\left(\mathrm{M}^{+}\right)$421.1348, found 421.1329 .

\section{(Z)-5-Chloropent-4-en-2-yn-1-ol (20)}

A stirred solution of (Z)-1,2-dichloroethene $(1.10 \mathrm{~mL}$, $14.57 \mathrm{mmol})$ in $\mathrm{Et}_{2} \mathrm{O}(15 \mathrm{~mL})$ was treated with $\mathrm{Pd}\left(\mathrm{PPh}_{3}\right)_{4}(386 \mathrm{mg}$, $0.335 \mathrm{mmol}), \mathrm{CuI}$ (206 mg, $1.082 \mathrm{mmol})$, and $\mathrm{Et}_{2} \mathrm{NH}(7.20 \mathrm{~mL}$, $69.60 \mathrm{mmol}$ ). Once a clear, homogeneous solution had been formed, prop-2-yn-1-ol (0.77 mL, $14.57 \mathrm{mmol})$ was added and stirring was continued for $3 \mathrm{~h}$ at ambient temperature. The reaction mixture was poured into two aliquots of a saturated aqueous solution of $\mathrm{NH}_{4} \mathrm{Cl}$ and the phases were separated. The organic layer was extracted with EtOAc $(33 \times 10 \mathrm{~mL})$, the combined organic phases were washed with $1 \mathrm{M} \mathrm{KHSO}_{4}(13 \times 20 \mathrm{~mL})$ and brine $(13 \times 20 \mathrm{~mL})$ followed by drying over $\mathrm{mgSO}_{4}$. Removal of the volatiles and purification of the crude product by bulb-to-bulb distillation $\left(110^{\circ} \mathrm{C}, 5.0\right.$ mbar) furnished 20 as a clear, colourless liquid (463 mg, $3.97 \mathrm{mmol}, 27 \%$ ). The characterisation data were consistent with those in ref.7a and ref.14d.

\section{(Z)-6-Chlorohex-5-en-3-yn-1-ol (21)}

The title compound was prepared using the same methodology as described for 20 by letting react $(Z)$-1,2-dichloroethene $(0.395 \mathrm{~mL}$, $5.232 \mathrm{mmol})$ in $\mathrm{Et}_{2} \mathrm{O}(10 \mathrm{~mL})$ with $\mathrm{PdCl}_{2}\left(\mathrm{PPh}_{3}\right)_{2}(130 \mathrm{mg}$, $0.112 \mathrm{mmol}), \mathrm{CuI}(77 \mathrm{mg}, 0.404 \mathrm{mmol}), \mathrm{Et}_{2} \mathrm{NH}(2.00 \mathrm{~mL}$, $19.33 \mathrm{mmol})$, and but-3-yn-1-ol $(0.300 \mathrm{~mL}, 3.963 \mathrm{mmol})$ over a period of $4 \mathrm{~h}$. Work-up followed by bulb-to-bulb distillation $\left(60{ }^{\circ} \mathrm{C}, 0.13 \mathrm{mbar}\right)$ gave 21 as a clear, colourless liquid $(284 \mathrm{mg}$, $2.175 \mathrm{mmol}, 55 \%$ ). The characterisation data were consistent with those in ref.7a.

\section{(Z)-7-chlorohept-6-en-4-yn-1-ol (22)}

The title compound was synthesised following the method described for 20. Thus, (Z)-1,2-dichloroethene $(0.500 \mathrm{~mL}$, $6.622 \mathrm{mmol})$ in $\mathrm{Et}_{2} \mathrm{O}(10 \mathrm{~mL})$ was allowed to react with $\mathrm{Pd}\left(\mathrm{PPh}_{3}\right)_{4}$ (217 mg, $0.188 \mathrm{~mol}), \mathrm{CuI}(108 \mathrm{mg}, 0.563 \mathrm{mmol}), \mathrm{Et}_{2} \mathrm{NH}(3.00 \mathrm{~mL}$, $29.00 \mathrm{mmol})$, and pent-4-yn-1-ol $(0.560 \mathrm{~mL}, 6.018 \mathrm{mmol})$ over a period of $7 \mathrm{~h}$. Work-up and purification by bulb-to-bulb distillation $\left(70{ }^{\circ} \mathrm{C}, 0.07 \mathrm{mbar}\right)$ afforded 22 as a clear, colourless liquid (785 mg, $5.429 \mathrm{mmol}, 90 \%$ ). The characterisation data were consistent with those in ref. $14 \mathrm{c}$.

\section{(Z)-10-Hydroxy-2-(toluene-4-sulfonylamino)dec-6-ene-4,8-diynoic acid methyl ester (23)}

The title compound was synthesised by a similar procedure as described for 13. Thus, $(Z)-5$-chloro-pent-4-en-2-yn-1-ol (20) (144 mg, $1.236 \mathrm{mmol})$ in $\mathrm{Et}_{2} \mathrm{O}(15 \mathrm{~mL})$ was allowed to react with $n-\mathrm{BuNH}_{2}(0.6 \mathrm{~mL}, 6.1 \mathrm{mmol}), \mathrm{CuI}(23 \mathrm{mg}, 0.121 \mathrm{mmol})$, $\mathrm{PdCl}_{2}\left(\mathrm{PPh}_{3}\right)_{2}(42 \mathrm{mg}, 0.060 \mathrm{mmol})$ and propargylglycine $( \pm)-9$ (396 mg, $1.408 \mathrm{mmol}$ ) over a period of $5 \mathrm{~h}$. Work-up and purification by flash chromatography (EtOAc/heptane, 2:3) yielded 23 as a yellowish solid (175 mg, $0.484 \mathrm{mmol}, 39 \%) . \mathrm{R}_{f} 0.30$ (EtOAc/heptane, 1:1); $v_{\max }$ (ATR) 3494, 3274, 2950, 1740, 1329; $\delta_{\mathrm{H}}\left(300 \mathrm{MHz}, \mathrm{CDCl}_{3}\right) 7.77(2 \mathrm{H}, \mathrm{d}, J=8.3 \mathrm{~Hz}), 7.29(2 \mathrm{H}, \mathrm{d}, J=$ $8.3 \mathrm{~Hz}), 5.93(1 \mathrm{H}, \mathrm{d}, J=7.8 \mathrm{~Hz}), 5.85(1 \mathrm{H}, \mathrm{td}, J=10.8,1.9 \mathrm{~Hz})$, $5.74(1 \mathrm{H}, \mathrm{td}, J=10.8,1.9 \mathrm{~Hz}), 5.51(2 \mathrm{H}, \mathrm{d}, J=6.5 \mathrm{~Hz}), 4.17$ $(1 \mathrm{H}, \mathrm{td}, J=4.5,9.0 \mathrm{~Hz}), 3.64(3 \mathrm{H}, \mathrm{s}), 3.03(1 \mathrm{H}, \mathrm{t}, J=6.5 \mathrm{~Hz})$, 2.96-2.81 (2 H, m), $2.42(3 \mathrm{H}, \mathrm{s}) ; \delta_{\mathrm{C}}\left(75 \mathrm{MHz}, \mathrm{CHCl}_{3}\right) 170.2$, 143.8, 136.9, 129.7, 127.1, 119.9, 119.3, 95.8, 90.4, 82.5, 82.0, 53.9, 53.1, 51.4, 25.3, 21.5; HRMS (EI) calcd. for $\mathrm{C}_{18} \mathrm{H}_{19} \mathrm{NO}_{5} \mathrm{~S}\left(\mathrm{M}^{+}\right)$ 361.0984, found 361.0991 .

\section{(Z)-11-Hydroxy-2-(toluene-4-sulfonylamino)-undec-6-ene-4,8- diynoic acid methyl ester (24)}

The title compound was prepared following a similar procedure as described for 13 by letting react $(Z)$-6-chlorohex-5-en-3-yn-1ol (21) (134 mg, $1.026 \mathrm{mmol})$ in $\mathrm{Et}_{2} \mathrm{O}(15 \mathrm{~mL})$ with $n-\mathrm{BuNH}_{2}$ (0.51 mL, $5.2 \mathrm{mmol}), \mathrm{PdCl}_{2}\left(\mathrm{PPh}_{3}\right)_{2}$ (38 mg, $\left.0.054 \mathrm{mmol}\right), \mathrm{CuI}$ $(0.104 \mathrm{mmol})$, and propargylglycine $( \pm)-9(311 \mathrm{mg}, 1.106 \mathrm{mmol})$ over a period of $4 \mathrm{~h}$. Work-up and flash chromatography 
(EtOAc/heptane, 1:10 $\rightarrow$ 1:1) afforded $\mathbf{2 4}$ as a yellow oil $(298 \mathrm{mg}$, $0.794 \mathrm{mmol}, 77 \%$ ). $\mathrm{R}_{f} 0.20$ (EtOAc/heptane, 1:1); $\mathrm{v}_{\max }(\mathrm{KBr}) 3444$, $3265,2953,2215,1753,1160 ; \delta_{\mathrm{H}}\left(300 \mathrm{MHz}, \mathrm{CDCl}_{3}\right) 7.76(1 \mathrm{H}, \mathrm{d}$, $J=8.3 \mathrm{~Hz}), 7.28(1 \mathrm{H}, \mathrm{d}, J=8.3 \mathrm{~Hz}), 6.18(1 \mathrm{H}, \mathrm{bs}), 5.79(1 \mathrm{H}$, $\mathrm{td}, J=10.8,2.1 \mathrm{~Hz}), 5.68(1 \mathrm{H}, \mathrm{td}, J=10.8,1.8 \mathrm{~Hz}), 4.15(1 \mathrm{H}$, $\mathrm{t}, J=4.7 \mathrm{~Hz}), 3.80(1 \mathrm{H}, \mathrm{t}, J=6.2 \mathrm{~Hz}), 3.60(1 \mathrm{H}, \mathrm{s}), 2.94-2.78$ $(2 \mathrm{H}, \mathrm{m}), 2.71(2 \mathrm{H}, \mathrm{dt}, J=6.2,1.5 \mathrm{~Hz}), 2.40(1 \mathrm{H}, \mathrm{s}) ; \delta_{\mathrm{C}}(75 \mathrm{MHz}$, $\left.\mathrm{CHCl}_{3}\right) 169.9,143.5,136.8,129.5,126.9,120.1,118.3,95.3,90.1$, 81.5, 79.5, 60.6, 54.0, 52.6, 24.8, 23.7, 21.3; HRMS (CI) calcd. for $\mathrm{C}_{19} \mathrm{H}_{22} \mathrm{NO}_{5} \mathrm{~S}\left(\mathrm{M}^{+}+\mathrm{H}\right) 376.1219$, found 376.1206.

\section{(Z)-12-Hydroxy-2-(toluene-4-sulfonylamino)-dodec-6-ene-4,8- diynoic acid methyl ester (25)}

The title compound was assembled similar to the preparation of 13. Thus, (Z)-7-chlorohept-6-en-4-yn-1-ol (22) $(88 \mathrm{mg}$, $0.609 \mathrm{mmol})$ in $\mathrm{Et}_{2} \mathrm{O}(15 \mathrm{~mL})$ was coupled to $( \pm)-9$ employing $\mathrm{PdCl}_{2}\left(\mathrm{PPh}_{3}\right)_{2}$ (20 mg, $\left.0.028 \mathrm{mmol}\right), \mathrm{CuI}$ (12 mg, $\left.0.063 \mathrm{mmol}\right)$, and $n-\mathrm{BuNH}_{2}(0.30 \mathrm{~mL}, 3.04 \mathrm{mmol})$. After stirring over night, work-up and flash chromatography (EtOAc/heptane, 1:10 $\rightarrow$ 1:1) yielded 25 as a yellowish oil (179 $\mathrm{mg}, 0.460 \mathrm{mmol}, 75 \%) . \mathrm{R}_{f} 0.31$ (EtOAc/heptane, 1:1); $v_{\max }$ (ATR) 3525, 3274, 3049, 2950, 2876, $2215,1744,1161 ; \delta_{\mathrm{H}}\left(300 \mathrm{MHz}, \mathrm{CDCl}_{3}\right) 7.76(2 \mathrm{H}, \mathrm{d}, J=8.3 \mathrm{~Hz})$, $7.28(2 \mathrm{H}, \mathrm{d}, J=8.3 \mathrm{~Hz}), 6.21(1 \mathrm{H}, \mathrm{d}, J=9.0 \mathrm{~Hz}), 5.78(1 \mathrm{H}, \mathrm{td}$, $J=10.8,2.2 \mathrm{~Hz}), 5.65(1 \mathrm{H}, \mathrm{td}, J=10.8,2.1 \mathrm{~Hz}), 4.13(1 \mathrm{H}, \mathrm{td}$, $J=9.1,5.2 \mathrm{~Hz}), 3.81(2 \mathrm{H}, \mathrm{t}, J=6.1 \mathrm{~Hz}), 3.60(3 \mathrm{H}, \mathrm{s}), 2.95-2.78$ (2 H, m), $2.70(1 \mathrm{H}, \mathrm{bs}), 2.56(2 \mathrm{H}, \mathrm{dt}, J=6.7,2.2 \mathrm{~Hz}), 2.40(3 \mathrm{H}$, s), $1.88-1.79(2 \mathrm{H}, \mathrm{m}) ; \delta_{\mathrm{C}}\left(75 \mathrm{MHz}, \mathrm{CHCl}_{3}\right) 170.1,143.5,136.8$, $129.5,126.9,120.3,117.9,97.9,89.9,81.4,78.5,61.3,54.0,52.6$, 30.8, 24.8, 21.3, 16.2; HRMS (CI) calcd. for $\mathrm{C}_{20} \mathrm{H}_{23} \mathrm{NO}_{5} \mathrm{~S}\left(\mathrm{M}^{+}\right)$ 390.1375 , found 390.1378 .

\section{2-Tosyl-1,2,3,4-tetrahydroisoquinoline-3-carboxylic acid methyl ester (26)}

Enediynic alcohol 23 (112 mg, $0.310 \mathrm{mmol})$ and $\mathrm{PPh}_{3}(121 \mathrm{mg}$, $0.461 \mathrm{mmol})$ were dissolved in THF $(75 \mathrm{~mL})$. Whilst stirring, DEAD $(0.075 \mathrm{~mL}, 0.476 \mathrm{mmol})$ was added via syringe and stirring was continued for $2 \mathrm{~h}$ at ambient temperature. All volatiles were removed in vacuo $\left(\mathrm{T}>30^{\circ} \mathrm{C}\right)$ and the crude product was purified by flash chromatography (EtOAc/heptane, 1:3 $\rightarrow 1: 1)$ providing 26 as a clear colourless oil (17 mg, $0.049 \mathrm{mmol}, 16 \%) . \mathrm{R}_{f} 0.78$ (EtOAc/heptane, 1:1); $v_{\max }$ (ATR) 3032, 2950, 2915, 1740, 1459, $1160 ; \delta_{\mathrm{H}}\left(300 \mathrm{MHz}, \mathrm{CDCl}_{3}\right) 7.72(2 \mathrm{H}, \mathrm{d}, J=8.3 \mathrm{~Hz}), 7.28(2 \mathrm{H}$, $\mathrm{d}, J=8.3 \mathrm{~Hz}), 7.19-7.02(4 \mathrm{H}, \mathrm{m}), 5.01(1 \mathrm{H}, \mathrm{t}, J=4.5 \mathrm{~Hz}), 4.70$ $(1 \mathrm{H}, \mathrm{d}, J=15.5 \mathrm{~Hz}), 4.49(1 \mathrm{H}, \mathrm{d}, J=15.5 \mathrm{~Hz}), 3.45(3 \mathrm{H}, \mathrm{s})$, $3.18(2 \mathrm{H}, \mathrm{d}, J=4.5 \mathrm{~Hz}), 2.41(3 \mathrm{H}, \mathrm{s}) ; \delta_{\mathrm{C}}\left(75 \mathrm{MHz}, \mathrm{CHCl}_{3}\right) 170.7$, $143.5,136.0,131.4,130.7,129.5,128.7,127.3,126.8$ (2 C), 126.1, 53.8, 52.2, 44.4, 31.9, 21.5; HRMS (EI) calcd. for $\mathrm{C}_{18} \mathrm{H}_{19} \mathrm{NO}_{4} \mathrm{~S}$ $\left(\mathrm{M}^{+}\right)$345.1035, found 345.0985.

\section{(Z)-2-(Toluene-4-sulfonylamino)undeca-6,10-diene-4,8-diynoic acid methyl ester (28)}

Enediynic alcohol 24 (134 mg, $0.357 \mathrm{mmol})$ was dissolved in THF (70 mL; c $=5 \mathrm{mM}) . \mathrm{PPh}_{3}(142 \mathrm{mg}, 0.541 \mathrm{mmol})$ was added to the stirred solution and once it had dissolved, DEAD ( $40 \%$ in toluene; $0.250 \mathrm{~mL}, 0.545 \mathrm{mmol}$ ) was transferred into the reaction vessel via syringe. Stirring was continued for $1 \mathrm{~h}$ at ambient temperature followed by removal of all volatiles in vacuo.
Flash chromatography (EtOAc/heptane, 1:10 $\rightarrow$ 1:3) of the crude product furnished 28 as a yellowish oil (44 mg, $0.123 \mathrm{mmol}, 34 \%$ ). $\mathrm{R}_{f} 0.56$ (EtOAc/heptane, 1:1); $v_{\max }(\mathrm{KBr}) 3470,3278,2955,2208$, $1744 ; \delta_{\mathrm{H}}\left(300 \mathrm{MHz}, \mathrm{CDCl}_{3}\right) 7.74(2 \mathrm{H}, \mathrm{d}, J=8.4 \mathrm{~Hz}), 7.28$ $(2 \mathrm{H}, \mathrm{d}, J=8.4 \mathrm{~Hz}), 6.04(1 \mathrm{H}, \mathrm{ddd}, J=17.5,11.1,2.3 \mathrm{~Hz})$, $5.91(1 \mathrm{H}, \mathrm{dd}, J=10.8,2.2 \mathrm{~Hz}), 5.77-5.69(2 \mathrm{H}, \mathrm{m}), 5.56(1 \mathrm{H}$, dd, $J=11.1,2.1 \mathrm{~Hz}), 5.47(1 \mathrm{H}, \mathrm{d}, J=9.2 \mathrm{~Hz}), 4.15(1 \mathrm{H}$, ddd, $J=9.2,5.4,4.3 \mathrm{~Hz}), 3.61(3 \mathrm{H}, \mathrm{s}), 2.92(1 \mathrm{H}, \mathrm{ddd}, J=$ 17.6, 4.3, $2.2 \mathrm{~Hz}), 2.83(1 \mathrm{H}, \mathrm{ddd}, J=17.6,5.41,2.2 \mathrm{~Hz}), 2.41$ $(3 \mathrm{H}, \mathrm{s}) ; \delta_{\mathrm{C}}\left(75 \mathrm{MHz}, \mathrm{CHCl}_{3}\right) 170.0,143.7,136.9,129.7,128.0$, 127.1, 119.8, 118.8, 117.1, 95.7, 90.9, 87.2, 81.6, 54.1, 52.8, 25.3, 21.5; HRMS (CI) calcd. for $\mathrm{C}_{19} \mathrm{H}_{20} \mathrm{NO}_{4} \mathrm{~S}\left(\mathrm{M}^{+}+\mathrm{H}\right) 358.1113$, found 358.1103 .

\section{(Z)-1-Tosyl-azacyclododec-6-ene-4,8-diyne-2-carboxylic acid methyl ester (29)}

Triphenylphosphine (164 mg, $0.624 \mathrm{mmol})$ was dissolved in a stirred, dilute solution $(\mathrm{c}=5 \mathrm{mM})$ of enediynic alcohol $25(161 \mathrm{mg}$, $0.413 \mathrm{mmol})$ in THF $(90 \mathrm{~mL})$. DEAD $(40 \%$ in toluene; $0.280 \mathrm{~mL}$, $0.612 \mathrm{mmol}$ ) was added and stirring was continued for $30 \mathrm{~min}$ at room temperature. Removal of the volatiles followed by flash chromatography (EtOAc/heptane, 1:10 $\rightarrow$ 1:4) afforded 29 as white, waxy solid (90 mg, $0.252 \mathrm{mmol}, 61 \%$ ). Crystals suitable for X-ray analysis could be grown from a $\mathrm{CHCl}_{3}$ solution toplayered with $\mathrm{MeOH} . \mathrm{R}_{f} 0.60$ (EtOAc/heptane, 1:1); $v_{\max }$ (ATR) $3023,2949,2193,1748,1333 ; \delta_{\mathrm{H}}\left(300 \mathrm{MHz}, \mathrm{CDCl}_{3}\right) 7.67(2 \mathrm{H}, \mathrm{d}$, $J=8.4 \mathrm{~Hz}), 7.30(2 \mathrm{H}, \mathrm{d}, J=8.4 \mathrm{~Hz}), 5.72(2 \mathrm{H}, \mathrm{d}, J=1.5 \mathrm{~Hz})$, $4.84(1 \mathrm{H}, \mathrm{dd}, J=6.4,2.4 \mathrm{~Hz}), 4.05-3.94(1 \mathrm{H}, \mathrm{m}), 3.84-3.73$ $(1 \mathrm{H}, \mathrm{m}), 3.56(3 \mathrm{H}, \mathrm{s}), 3.25(1 \mathrm{H}, \mathrm{tdd}, J=17.6,6.4,1.6 \mathrm{~Hz})$, $2.73(1 \mathrm{H}, \mathrm{dd}, J=17.6,2.4 \mathrm{~Hz}), 2.51-2.21(3 \mathrm{H}, \mathrm{m}), 2.43(3 \mathrm{H}$, s), 2.07-1.93 $(1 \mathrm{H}, \mathrm{m}) ; \delta_{\mathrm{C}}\left(75 \mathrm{MHz}, \mathrm{CHCl}_{3}\right) 169.1,143.5,136.2$, $129.5,127.2,121.9,120.6,98.4,91.8,82.1,81.2,57.6,52.2,45.6$, 30.7, 23.8, 21.4, 17.3; HRMS (EI) calcd. for $\mathrm{C}_{20} \mathrm{H}_{21} \mathrm{NO}_{4} \mathrm{~S}\left(\mathrm{M}^{+}\right)$ 371.1191 , found 371.1181 .

\section{(Z)-(S)-11-Hydroxy-2-(toluene-4-sulfonylamino)undec-7-ene-5,9- diynoic acid methyl ester (31)}

The title compound was prepared using a similar procedure as described for 13: Protected $(S)$-homopropargylglycine $30(247 \mathrm{mg}$, $0.836 \mathrm{mmol})$ was coupled to $(Z)-5$-chloropent-4-en-2-yn-1-ol (20) (100 mg, $0.858 \mathrm{mmol})$ by the action of $\mathrm{Pd}\left(\mathrm{PPh}_{3}\right)_{4} 950 \mathrm{mg}$, $0.043 \mathrm{mmol}), \mathrm{CuI}(18 \mathrm{mg}, 0.095 \mathrm{mmol})$, and $n-\mathrm{BuNH}_{2}(0.50 \mathrm{~mL}$, $5.1 \mathrm{mmol})$ in $\mathrm{Et}_{2} \mathrm{O}(40 \mathrm{~mL})$ over a period of $5 \mathrm{~h}$. Work-up and flash chromatography (EtOAc/heptane, 1:2 $\rightarrow 1: 1$ ) gave access to 31 as a yellowish solid (265 $\mathrm{mg}, 0.706 \mathrm{mmol}, 84 \%) . \mathrm{R}_{f} 0.23$ (EtOAc/heptane, 1:1); $[\alpha]^{22}=+50.0^{\circ}\left(c 0.11, \mathrm{CH}_{2} \mathrm{Cl}_{2}\right) ; v_{\max }$ (ATR) 3511, 3270, 2949, 1744, 1433, 1338; $\delta_{\mathrm{H}}\left(300 \mathrm{MHz}, \mathrm{CDCl}_{3}\right)$ $7.76(2 \mathrm{H}, \mathrm{d}, J=8.4 \mathrm{~Hz}), 7.29(2 \mathrm{H}, \mathrm{d}, J=8.4 \mathrm{~Hz}), 5.82(1 \mathrm{H}$, $\mathrm{td}, J=10.9,1.8 \mathrm{~Hz}), 5.76(1 \mathrm{H}, \mathrm{td}, J=10.9,2.0 \mathrm{~Hz}), 5.34$ $(1 \mathrm{H}, \mathrm{d}, J=9.2 \mathrm{~Hz}), 4.46(1 \mathrm{H}, \mathrm{dd}, J=6.5,1.8 \mathrm{~Hz}), 4.19-4.11$ $(1 \mathrm{H}, \mathrm{m}), 3.59(3 \mathrm{H}, \mathrm{s}), 2.58(1 \mathrm{H}, \mathrm{t}, J=6.5 \mathrm{~Hz}), 2.49(2 \mathrm{H}$, $\mathrm{dt}, J=6.6,2.0 \mathrm{~Hz}), 2.42(3 \mathrm{H}, \mathrm{s}), 2.08-1.97(1 \mathrm{H}, \mathrm{m}), 1.94-1.82$ $(1 \mathrm{H}, \mathrm{m}) ; \delta_{\mathrm{C}}\left(75 \mathrm{MHz}, \mathrm{CHCl}_{3}\right) 172.0,143.8,136.5,129.7,127.3$, 120.0, 118.7, 95.9, 95.2, 82.6, 79.5, 54.9, 52.8, 51.5, 31.8, 21.6, 15.9; HRMS (ESI) calcd. for $\mathrm{C}_{19} \mathrm{H}_{21} \mathrm{NNaO}_{5} \mathrm{~S}\left(\mathrm{M}^{+}+\mathrm{Na}\right) 398.1038$, found 398.1045 . 
(S)-6-[2-(3-Hydroxy-prop-1-ynyl)phenyl]-2-(toluene-4sulfonylamino)-hex-5-ynoic acid methyl ester (32)

The title compound was synthesised following a similar procedure as used for 13. Thus, 3-(2-iodophenyl)prop-2-yn-1-ol (10) $(130 \mathrm{mg}, 0.504 \mathrm{mmol})$ in $\mathrm{Et}_{2} \mathrm{O}(25 \mathrm{~mL})$ was allowed to react with $\mathrm{PdCl}_{2}\left(\mathrm{PPh}_{3}\right)_{2}(18 \mathrm{mg}, 0.026 \mathrm{~mol}), \mathrm{CuI}(10 \mathrm{mg}$, $0.053 \mathrm{mmol}), n-\mathrm{BuNH}_{2}(0.26 \mathrm{~mL}, 2.63 \mathrm{mmol})$ and protected (S)-homopropargylglycine 30 (146 $\mathrm{mg}, 0.494 \mathrm{mmol}$ ) over a period of $5.5 \mathrm{~h}$. Work-up followed by flash chromatography (EtOAc/heptane, 1:10 $\rightarrow$ 1:1) furnished 32 as a yellow solid (139 mg, $0.327 \mathrm{mmol}, 66 \%$ ). $\mathrm{R}_{f} 0.20$ (EtOAc/heptane, 1:1); $[\alpha]^{22}{ }_{\mathrm{D}}=+26.9^{\circ}\left(c\right.$ 1.0, $\mathrm{CH}_{2} \mathrm{Cl}_{2}$ ); $v_{\max }$ (ATR) 3499, 3261, 2950, $1735,1432,1337 ; \delta_{\mathrm{H}}\left(300 \mathrm{MHz}, \mathrm{CDCl}_{3}\right) 7.74(2 \mathrm{H}, \mathrm{d}, J=8.4 \mathrm{~Hz})$, 7.45-7.39 (1 H, m), 7.36-7.30 (1 H, m), 7.26-7.20 (2 H, m), 7.16 $(2 \mathrm{H}, \mathrm{d}, J=8.4 \mathrm{~Hz}), 5.80(1 \mathrm{H}, \mathrm{d}, J=9.1 \mathrm{~Hz}), 4.55(2 \mathrm{H}, \mathrm{d}, J=$ $6.0 \mathrm{~Hz}), 4.19(1 \mathrm{H}, \mathrm{dt}, J=8.6,5.0 \mathrm{~Hz}), 3.56(3 \mathrm{H}, \mathrm{s}), 3.11(1 \mathrm{H}, \mathrm{t}$, $J=6.0 \mathrm{~Hz}), 2.54(2 \mathrm{H}, \mathrm{t}, J=6.6 \mathrm{~Hz}), 2.30(3 \mathrm{H}, \mathrm{s}), 2.13-2.02(1 \mathrm{H}$, m), 1.99-1.87 (1 H, m); $\delta_{\mathrm{C}}\left(75 \mathrm{MHz}, \mathrm{CHCl}_{3}\right) 172.1,143.6,136.4$, $132.1,131.7,129.5,127.9,127.5,127.2,125.8,125.1,91.8,91.6$, 83.9, 80.6, 54.9, 52.7, 51.3, 31.6, 21.4, 15.7; HRMS (ESI) calcd. for $\mathrm{C}_{23} \mathrm{H}_{23} \mathrm{NNaO}_{5} \mathrm{~S}\left(\mathrm{M}^{+}+\mathrm{Na}\right) 448.1195$, found 448.1194 .

\section{$(Z)-(S)$-1-Tosyl-azacycloundec-7-en-5,9-diyne-2-carboxylic acid methyl ester (33)}

In a stirred solution of enediynic alcohol 31 (103 $\mathrm{mg}, 0.274 \mathrm{mmol})$ in THF (55 mL; c $=5 \mathrm{mM})$ was dissolved $\mathrm{PPh}_{3}(86 \mathrm{mg}$, $0.380 \mathrm{mmol})$ followed by the addition of DEAD ( $40 \%$ in toluene; $0.150 \mathrm{~mL}, 0.327 \mathrm{mmol})$. Stirring was continued for $15 \mathrm{~min}$ at ambient temperature, then all volatiles were removed in vacuo at room temperature. Purification of the crude product by flash chromatography (EtOAc/heptane, 1:4) afforded the title compound an off-white solid (69 $\mathrm{mg}, 0.193 \mathrm{mmol}, 70 \%) . \mathrm{R}_{f}$ 0.62 (EtOAc/heptane, $1: 1) ;[\alpha]^{22}{ }_{\mathrm{D}}=+131.9^{\circ}\left(\mathrm{c} 0.72, \mathrm{CH}_{2} \mathrm{Cl}_{2}\right.$ ); $v_{\max }(\mathrm{ATR}) 3023,2950,2915,2842,2198,1731,1433,1333 ; \delta_{\mathrm{H}}$ $\left(300 \mathrm{MHz}, \mathrm{CDCl}_{3}\right) 7.69(2 \mathrm{H}, \mathrm{d}, J=8.4 \mathrm{~Hz}), 7.31(2 \mathrm{H}, \mathrm{d}, J=$ $8.4 \mathrm{~Hz}), 5.83(1 \mathrm{H}, \mathrm{d}, J=10.4 \mathrm{~Hz}), 5.79(1 \mathrm{H}, \mathrm{d}, J=10.4 \mathrm{~Hz}), 5.25$ $(1 \mathrm{H}, \mathrm{dd}, J=8.9,2.5 \mathrm{~Hz}), 4.49(1 \mathrm{H}, \mathrm{d}, J=17.9 \mathrm{~Hz}), 4.38(1 \mathrm{H}$, $\mathrm{d}, J=17.9 \mathrm{~Hz}), 3.64(3 \mathrm{H}, \mathrm{s}), 2.79-2.69(1 \mathrm{H}, \mathrm{m}), 2.63-2.55(2 \mathrm{H}$, m), $2.42(3 \mathrm{H}, \mathrm{s}), 2.12-2.01(1 \mathrm{H}, \mathrm{m}) ; \delta_{\mathrm{C}}\left(75 \mathrm{MHz}, \mathrm{CHCl}_{3}\right) 171.7$, 143.6, 137.8, 129.7, 127.0, 122.6, 120.1, 99.4, 91.0, 86.7, 81.8, 57.1, 52.2, 41.9, 33.0, 21.5, 19.1; HRMS (ESI) calcd. for $\mathrm{C}_{19} \mathrm{H}_{19} \mathrm{NNaO}_{4} \mathrm{~S}$ $\left(\mathrm{M}^{+}+\mathrm{Na}\right) 380.0933$, found 380.0960 .

\section{(S)-4-Tosyl-1,2,8,9-tetradehydro-4,5,6,7-tetrahydro-3H-4-} benzazacycloundecine-5-carboxylic acid methyl ester (34)

Enediynic alcohol 32 (126 mg, $0.296 \mathrm{mmol})$ was dissolved in THF $(60 \mathrm{~mL} ; \mathrm{c}=5 \mathrm{mM})$. Whilst stirring, $\mathrm{PPh}_{3}(93 \mathrm{mg}, 0.355 \mathrm{mmol})$ and DEAD ( $40 \%$ in toluene; $0.165 \mathrm{~mL}, 0.360 \mathrm{mmol})$ were added, and stirring was continued for $15 \mathrm{~min}$, then all volatiles were removed in vacuo. The crude product was subjected to flash chromatography (EtOAc/heptane, 1:10 $\rightarrow$ 1:4) to yield 34 as a white solid $(96 \mathrm{mg}$, $0.236 \mathrm{mmol}, 80 \%$ ). Crystals suitable for $\mathrm{X}$-ray analysis could be grown from a $\mathrm{CHCl}_{3}$ solution top-layered with $\mathrm{MeOH} . \mathrm{R}_{f}$ 0.70 (EtOAc/heptane, $1: 1) ;[\alpha]^{22}{ }_{\mathrm{D}}=+37.0^{\circ}\left(\mathrm{c} 0.30, \mathrm{CH}_{2} \mathrm{Cl}_{2}\right.$ ); $v_{\max }(\mathrm{ATR}) 3062,2950,2915,2846,2228,1735,1445,1329 ; \delta_{\mathrm{H}}$ $\left(300 \mathrm{MHz} \mathrm{CDCl}_{3}\right) 7.72(2 \mathrm{H}, \mathrm{d}, J=8.4 \mathrm{~Hz}), 7.34-7.18(6 \mathrm{H}$, m), $5.23(1 \mathrm{H}, \mathrm{dd}, J=8.2,3.5 \mathrm{~Hz}), 4.58(1 \mathrm{H}, \mathrm{d}, J=17.5 \mathrm{~Hz})$,
$4.44(1 \mathrm{H}, \mathrm{d}, J=17.5 \mathrm{~Hz}), 3.65(3 \mathrm{H}, \mathrm{s}), 2.76-2.66(1 \mathrm{H}, \mathrm{m})$, 2.64-2.59 (2 H, m), $2.40(3 \mathrm{H}, \mathrm{s}), 2.21-2.11(1 \mathrm{H}, \mathrm{m}) ; \delta_{\mathrm{C}}(50 \mathrm{MHz}$, $\left.\mathrm{CHCl}_{3}\right)$ 171.6, 143.6, 137.7, 129.7, 129.4, 129.3, 128.2, 127.5, 127.1, 126.9, 126.0, 95.1, 87.5, 86.9, 82.0, 57.6, 52.2, 41.7, 32.0, 21.4, 18.5; HRMS (ESI) calcd. for $\mathrm{C}_{23} \mathrm{H}_{21} \mathrm{NNaO}_{4} \mathrm{~S}\left(\mathrm{M}^{+}+\mathrm{Na}\right) 430.1089$, found 430.1092 .

\section{(S)-2-Tosyl-2,3,4,5-tetrahydro-1 $H$-benzo[c]azepine-3-carboxylic acid methyl ester (35)}

Cyclic enediyne 33 (78 mg, $0.218 \mathrm{mmol})$ was dissolved in EtCN (10 mL), 1,4-cyclohexadiene (2.06 mL, $21.8 \mathrm{mmol}, 100$ equiv.) was added, and the reaction mixture was heated to reflux under a protective atmosphere of nitrogen for $6 \mathrm{~d}$. All volatiles were removed and the crude product was purified by flash chromatography (EtOAc/heptane, 1:4) to give 35 as a white solid (24 mg, $0.067 \mathrm{mmol}, 31 \%)$. $\mathrm{R}_{f} 0.60($ EtOAc/heptane, $1: 1) ;[\alpha]^{22}{ }_{\mathrm{D}}=58.1^{\circ}$ $\left(c=0.42, \mathrm{CH}_{2} \mathrm{Cl}_{2}\right) ; v_{\max }(\mathrm{ATR}) 3031,2950,1740,1437,1333 ; \delta_{\mathrm{H}}$ $\left(400 \mathrm{MHz}, \mathrm{CDCl}_{3}\right) 7.49(2 \mathrm{H}, \mathrm{d}, J=8.4 \mathrm{~Hz}), 7.21-7.18(1 \mathrm{H}$, m), 7.16-7.11 (4 H, m), 7.00-6.96 (1 H, m), 4.81-4.73 (2 H, m), $4.64(1 \mathrm{H}, \mathrm{d}, J=16.5 \mathrm{~Hz}), 3.67$ ( $3 \mathrm{H}, \mathrm{s}), 2.90$ (1 H, dd, $J=15.8$, $10.1 \mathrm{~Hz}), 2.59(1 \mathrm{H}, \mathrm{dd}, J=15.8,9.3 \mathrm{~Hz}), 2.36(3 \mathrm{H}, \mathrm{s}), 2.34-2.26$ $(1 \mathrm{H}, \mathrm{m}), 2.00-1.92(1 \mathrm{H}, \mathrm{m}) ; \delta_{\mathrm{C}}\left(75 \mathrm{MHz}, \mathrm{CHCl}_{3}\right) 171.4,143.0$, $139.9,137.2,136.7,129.4,129.2,128.7,127.6,127.1,126.3,59.2$, 52.3, 48.6, 31.4, 29.3, 21.4; HRMS (ESI) calcd. for $\mathrm{C}_{19} \mathrm{H}_{21} \mathrm{NNaO}_{4} \mathrm{~S}$ $\left(\mathrm{M}^{+}+\mathrm{Na}\right) 382.1089$, found 382.1082 .

\section{(S)-2-Tosyl-2,3,4,5-tetrahydro-1 $H$-naphtho[2,3-c]azepine-3- carboxylic acid methyl ester (36)}

Cyclic enediyne 34 (15 mg, $0.037 \mathrm{mmol})$, EtCN (3 mL), and 1,4cyclohexadiene $(0.35 \mathrm{~mL}, 3.70 \mathrm{mmol}, 100$ equiv.) were enclosed in a sealed tube under a protective atmosphere of nitrogen. The reaction vessel was exposed to a temperature of $150{ }^{\circ} \mathrm{C}$ for $9 \mathrm{~d}$ after which time the volatiles were removed and the crude product was subjected to preparative TLC $\left(0.5 \% \mathrm{MeOH}\right.$ in $\left.\mathrm{CH}_{2} \mathrm{Cl}_{2}\right)$ resulting in 36 as a white solid ( $9 \mathrm{mg}, 0.022 \mathrm{mmol}, 60 \%) . \mathrm{R}_{f}$ 0.49 (EtOAc/heptane, 1:2); $[\alpha]^{22}{ }_{\mathrm{D}}=1.1^{\circ}\left(c=0.45, \mathrm{CH}_{2} \mathrm{Cl}_{2}\right) ; v_{\max }$ (ATR) 2936, 1733, 1592, 1420, 1333; $\delta_{\mathrm{H}}\left(400 \mathrm{MHz}, \mathrm{CDCl}_{3}\right) 7.79-$ 7.75 (1 H, m), 7.73-7.69 (1 H, m), 7.67 (1 H, s), 7.51 (1 H, s), 7.48 $(2 \mathrm{H}, \mathrm{d}, J=2.3 \mathrm{~Hz}), 7.46-7.42(2 \mathrm{H}, \mathrm{m}), 7.03(2 \mathrm{H}, \mathrm{d}, J=8.4 \mathrm{~Hz})$, $4.94(1 \mathrm{H}, \mathrm{d}, J=16.3 \mathrm{~Hz}), 4.86(1 \mathrm{H}, \mathrm{t}, J=5.1 \mathrm{~Hz}), 4.72(1 \mathrm{H}$, $\mathrm{d}, J=16.3 \mathrm{~Hz}), 3.70(3 \mathrm{H}, \mathrm{s}), 3.07(1 \mathrm{H}, \mathrm{dd}, J=15.3,11.2 \mathrm{~Hz})$, $2.82(1 \mathrm{H}, \mathrm{dd}, J=15.3,8.1 \mathrm{~Hz}), 2.48-2.41(1 \mathrm{H}, \mathrm{m}), 2.28(3 \mathrm{H}$, s), $1.95-1.87(1 \mathrm{H}, \mathrm{m}) ; \delta_{\mathrm{C}}\left(75 \mathrm{MHz}, \mathrm{CHCl}_{3}\right) 171.3,143.1,138.2$, 137.2, 135.1, 132.9, 132.0, 129.2, 127.7, 127.6, 127.5, 127.2, 127.0, 126.1, 125.7, 59.0, 52.4, 49.0, 31.6, 30.1, 21.4; HRMS (ESI) calcd. for $\mathrm{C}_{23} \mathrm{H}_{24} \mathrm{NO}_{4} \mathrm{~S}\left(\mathrm{M}^{+}+\mathrm{H}\right) 410.1426$, found 410.1422 .

\section{Half-life determination of the cyclic enediynes}

High temperature NMR experiments $\left(\mathbf{T} \leq 80^{\circ} \mathbf{C}\right)$. The NMR probe was heated to a set temperature and allowed to equilibrate until the internal temperature remained constant. ${ }^{31}$ A sealed NMR tube containing an enediyne sample (vide infra) was inserted and ${ }^{1} \mathrm{H}-\mathrm{NMR}$ spectra were recorded at different points in time.

High temperature experiments $\left(\mathbf{T}>\mathbf{8 0}{ }^{\circ} \mathbf{C}\right)$. A sealed NMR tube containing the enediyne sample (vide infra) was immersed into an oil bath of constant temperature. In regular intervalls, 
the NMR tube was removed from the oil bath and immediately cooled to room temperature by rinsing with heptane and acetone. The conversion of the $\mathrm{BC}$ was then controlled by ${ }^{1} \mathrm{H}-\mathrm{NMR}$.

For enediyne 4. A NMR tube $(\varnothing=5 \mathrm{~mm})$ connected to an argon/vacuum manifold was charged with enediyne $\mathbf{4}$ $(20.3 \mathrm{mg}, 0.052 \mathrm{mmol})$ and DMSO- $d_{6}(450 \mu \mathrm{L})$. Of a solution of 1,4-cyclohexadiene in DMSO- $d_{6}(10 \% \mathrm{v} / \mathrm{v})$ was added $97 \mu \mathrm{L}$ ( $0.103 \mathrm{mmol}, 2$ equiv.). Cyclohexane was added as internal standard as a solution in DMSO- $d_{6}(10 \% \mathrm{v} / \mathrm{v})(14 \mu \mathrm{L}, 0.013 \mathrm{mmol})$. The resulting solution was degassed by three freeze-pump-thaw cycles and the NMR tube was tipped-off by flame under partial vacuum. The concentration of $\mathbf{4}$ in the thus prepared sample was $0.093 \mathrm{M}$. Decay of the starting material and formation of product were monitored by high temperature NMR experiments $\left(\mathrm{T}=80^{\circ} \mathrm{C}\right)$. The decay of $\mathbf{4}$ displayed first-order behaviour. $t_{1 / 2}$ $\left(80^{\circ} \mathrm{C}\right)=59 \mathrm{~min}$.

For enediyne 19. A sample was prepared as described for $\mathbf{4}$ from enediyne 19 (21.8 $\mathrm{mg}, 0.052 \mathrm{mmol})$ in DMSO- $d_{6}(450 \mu \mathrm{L})$, 1,4-cyclohexadiene in DMSO- $d_{6}(10 \% \mathrm{v} / \mathrm{v})(98 \mu \mathrm{L}, 0.104 \mathrm{mmol}$, 2 equiv.), and cyclohexane in DMSO- $d_{6}(10 \% \mathrm{v} / \mathrm{v})(14 \mu \mathrm{L}$, $0.013 \mathrm{mmol}$ ) as internal standard. The concentration of 19 in the final solution was $0.093 \mathrm{M}$. No decay of $\mathbf{1 9}$ could be observed up to temperatures of $120^{\circ} \mathrm{C}$.

For enediyne 29. A sample was prepared as described for $\mathbf{4}$ from enediyne $29(19.3 \mathrm{mg}, 0.052 \mathrm{mmol})$ in DMSO- $d_{6}(450 \mu \mathrm{L})$, 1,4-cyclohexadiene in DMSO- $d_{6}(10 \% \mathrm{v} / \mathrm{v})(98 \mu \mathrm{L}, 0.104 \mathrm{mmol}$, 2 equiv.), and cyclohexane in DMSO- $d_{6}(10 \% \mathrm{v} / \mathrm{v})(14 \mu \mathrm{L}$, $0.013 \mathrm{mmol}$ ) as internal standard. The resulting concentration of 29 was $0.093 \mathrm{M}$. No decay of the enediyne was observed at temperatures of $90^{\circ} \mathrm{C}$. After being subjected to $120^{\circ} \mathrm{C}$ for $24 \mathrm{~h}$, a trace amount of a decay product appeared in the ${ }^{1} \mathrm{H}-\mathrm{NMR}$ spectra.

For enediyne 33. A sample was prepared as described for $\mathbf{4}$ from enediyne $33(17.8 \mathrm{mg}, 0.050 \mathrm{mmol})$ in DMSO- $d_{6}(500 \mu \mathrm{L})$, 1,4-cyclohexadiene $(9.5 \mu \mathrm{L}, 0.100 \mathrm{mmol})$, and a solution of dimethyl oxalate in DMSO- $d_{6}(2.5 \mathrm{M})(10 \mu \mathrm{L}, 0.025 \mathrm{mmol})$ as internal standard. The concentration of $\mathbf{3 3}$ in the sample was 0.096 M. Decay of $\mathbf{3 3}$ and formation of $\mathbf{3 5}$ were followed at $90^{\circ} \mathrm{C}$. The decay of $\mathbf{3 3}$ displayed first-order behaviour. $t_{1 / 2}\left(90^{\circ} \mathrm{C}\right)=26 \mathrm{~h}$.

For enediyne 34. A sample was prepared as described for $\mathbf{4}$ from enediyne $34(12.3 \mathrm{mg}, 0.030 \mathrm{mmol})$ in DMSO- $d_{6}(550 \mu \mathrm{L})$, 1,4-cyclohexadiene ( $5.7 \mu \mathrm{L}, 0.060 \mathrm{mmol}, 2$ equiv.), and $\mathrm{MeCN}$ in DMSO- $d_{6}(10 \%$ v/v) $(16 \mu \mathrm{L}, 0.031 \mathrm{mmol})$ as internal standard. The final concentration of $\mathbf{3 4}$ was $0.053 \mathrm{M}$. Decay of $\mathbf{3 4}$ and formation of $\mathbf{3 6}$ were followed at $120^{\circ} \mathrm{C}$. The decay of $\mathbf{3 4}$ displayed first-order behaviour. $t_{1 / 2}\left(120^{\circ} \mathrm{C}\right)=175 \mathrm{~h}$.

\section{Acknowledgements}

AstraZeneca (Macclesfield, UK) is kindly acknowledged for financial support. Paul Schlebos (Institute for Molecules and Materials, Radboud University Nijmegen, NL) is kindly thanked for assistance with NMR experiments.

\section{Notes and references}

1 For general reviews of natural enediynes see: (a) U. Galm, M. H. Hager, S. G. Van Lanen, J. H. Ju, J. S. Thorson and B. Shen, Chem. Rev., 2005,
105, 739; (b) A. L. Smith and K. C. Nicolaou, J. Med. Chem., 1996, 39, 2103.

2 K. C. Nicolaou, Y. Ogawa, G. Zuccarello and H. Kataoka, J. Am. Chem. Soc., 1988, 110, 7247.

3 (a) R. R. Jones and R. G. Bergman, J. Am. Chem. Soc., 1972, 94, 660; (b) R. G. Bergman, Acc. Chem. Res., 1973, 6, 25.

4 "Endiine", in Römpp kompakt Basislexikon der Chemie, Georg Thieme Verlag, Stuttgart, $1^{\text {st }}$ edition, 1998, vol. 1, p. 661.

5 P. F. Bross, J. Beitz, G. Chen, X. H. Chen, E. Duffy, L. Kieffer, S. Roy, R. Sridhara, A. Rahman, G. Williams and R. Pazdur, Clin. Cancer Res., 2001, 7, 1490.

6 For reviews, see: (a) M. Kar and A. Basak, Chem. Rev., 2007, 107, 2861; (b) D. S. Rawat and J. M. Zaleski, Synlett, 2004, 393; (c) A. Basak, S. Mandal and S. S. Bag, Chem. Rev., 2003, 103, 4077.

7 (a) A. Basak, J. C. Shain, U. K. Khamrai, K. R. Rudra and A. Basak, J. Chem. Soc. Perkin Trans. 1, 2000, 1955; (b) A. Basak, S. Mandal, A. K. Das and V. Bertolasi, Bioorg. Med. Chem. Lett., 2002, 12, 873.

8 L. Banfi and G. Guanti, Eur. J. Org. Chem., 2002, 3745.

9 Y. M. Du, C. J. Creighton, Z. Y. Yan, D. A. Gauthier, J. P. Dahl, B. Zhao, S. M. Belkowski and A. B. Reitz, Bioorg. Med. Chem., 2005, 13, 5936.

10 B. C. J. van Esseveldt, Synthesis of Multi-Functional Building Blocks from Acetylene-Containing $\alpha$-Amino Acids, Ph.D. Thesis, Radboud University Nijmegen, 2004.

11 (a) R. D. Stephens and C. E. Castro, J. Org. Chem., 1963, 28, 3313; (b) K. Sonogashira, Y. Tohda and N. Hagihara, Tetrahedron Lett., $1975,4467$.

12 For a review on unsaturated $\alpha-H-\alpha$-amino acids see: J. Kaiser, S. S. Kinderman, B. C. J. van Esseveldt, F. L. van Delft, H. E. Schoemaker, R. H. Blaauw and F. P. J. T. Rutjes, Org. Biomol. Chem., 2005, 3, 3435.

13 Intramolecular displacement of a mesylate has been successfully used in the preparation of enediynes $\mathbf{1}$, see ref. 7.

14 (a) J. W. Grissom, D. Klingberg, D. H. Huang and B. J. Slattery, J. Org. Chem., 1997, 62, 603; (b) J. W. Grissom, D. Klingberg, S. Meyenburg and B. L. Stallman, J. Org. Chem., 1994, 59, 7876; (c) J. W. Grissom, T. L. Calkins and H. A. McMillen, J. Org. Chem., 1993, 58, 6556; (d) A. Hamze, O. Provot, J. D. Brion and M. Alami, J. Org. Chem., 2007, 72, 3868; see also ref.7.

15 Fully protected propargylglycine and homopropargylglycine were prepared according to L. B. Wolf, K. C. M. F. Tjen, H. T. ten Brink, R. H. Blaauw, H. Hiemstra, H. E. Schoemaker and F. P. J. T. Rutjes, $A d v$. Synth. Catal., 2002, 344, 70.

16 For an early report of Sonogashira couplings on propargylglycine, see: G. T. Crisp and P. T. Glink, Tetrahedron Lett., 1992, 33, 4649.

17 (a) C. J. M. Stirling, Chem. Rev., 1978, 78, 517; (b) R. J. Palmer and C. J. M. Stirling, J. Am. Chem. Soc., 1980, 102, 7888.

18 Drawing generated by PLATON: A. L. Spek, PLATON, A Multipurpose Crystallographic Tool, Utrecht University, Utrecht, The Netherlands, 2002.

19 In order to attenuate the $\alpha-\mathrm{H}$ acidity of the 10 -membered cyclic enediyne, the mesylated cyclisation precursor was assembled with a Boc instead of a Ts protecting group. This compound required long reaction times and strong bases ( $\mathrm{NaH}$ or KHMDS in THF) to give the cyclic enediynes in very low yields.

20 O. Mitsunobu and M. Yamada, Bull. Chem. Soc. Jpn., 1967, 40, 2380.

21 (a) J. R. Henry, L. R. Marcin, M. C. McIntosh, P. M. Scola, G. D. Harris and S. M. Weinreb, Tetrahedron Lett., 1989, 30, 5709; (b) D. Papaioannou, C. Athanassopoulos, V. Magafa, N. Karamanos, G. Stavropoulos, A. Napoli, G. Sindona, D. W. Aksnes and G. W. Francis, Acta Chem. Scand., 1994, 48, 324; (c) K. Wisniewski, A. S. Koldziejczyk and B. Falkiewicz, J. Pept. Sci., 1998, 4, 1.

22 Similar stability was reported by Du et al. (ref. 9).

23 The extent of optical purity has not been determined.

24 Supplementary crystallographic data for this paper has been deposited with The Cambridge Crystallographic Data Centre as CCDC 237705 (compound 4), CCDC 698982 (compound 29), CCDC 698983 (compound 19) and CCDC 698984 (compound 34). These data can be obtained free of charge via www.ccdc.cam.ac.uk/data_request/cif $\dagger$.

25 (a) K. C. Nicolaou, G. Zuccarello, Y. Ogawa, E. J. Schweiger and T. Kumazawa, J. Am. Chem. Soc., 1988, 110, 4866; (b) P. R. Schreiner, J. Am. Chem. Soc., 1998, 120, 4184.

26 (a) P. Magnus, S. Fortt, T. Pitterna and J. P. Snyder, J. Am. Chem. Soc., 1990, 112, 4986; (b) J. P. Snyder, J. Am. Chem. Soc., 1990, 112, 5367.

27 See for example:(a) K. C. Nicolaou, W. M. Dai, Y. P. Hong, S. C. Tsay, K. K. Baldridge and J. S. Siegel, J. Am. Chem. Soc., 1993, 115, 7944; 
(b) M. F. Semmelhack, T. Neu and F. Foubelo, J. Org. Chem., 1994, 59, 5038; (c) S. Bhattacharyya, M. Pink, M. H. Baik and J. M. Zaleski, Angew. Chem. Int. Ed., 2005, 44, 592.

28 The dependence of the $\mathrm{BC}$ rate on the radical trap concentration in some cases was first reported in: (a) M. F. Semmelhack, T. Neu and F. Foubelo, Tetrahedron Lett., 1992, 33, 3277. For studies concerning this matter, see: T. Kaneko, M. Takahashi and M. Hirama, Tetrahedron Lett., 1999, 40, 2015; (b) S. Koseki, Y. Fujimura and M. Hirama, J. Phys. Chem. A, 1999, 103, 7672; (c) G. B. Jones and P. M. Warner, J. Am. Chem. Soc., 2001, 123, 2134.

29 The temperature difference presumably is the main reason for the pronounced difference between the half lives of enediyne $\mathbf{4}$ as measured by Du et al. (ref. 9) and in this report. Other factors, however, cannot be excluded such as solvent effects (DMF vs. DMSO- $d_{6}$ ) and also, even though the reaction followed (pseudo) first order kinetics, the concentration of the enediyne $\left(10^{-4} \mathrm{M}\right.$ vs. $\left.10^{-1} \mathrm{M}\right)$ and the amount of CHD (100 equiv. vs. 2 equiv.).

30 The cycloaromatisation product of $\mathbf{4}$ has been described in ref. 9.

31 The internal temperature was determined by observing the peak separation of 1,2-ethanediol $\left(80 \%\right.$ in DMSO- $\left.d_{6}\right)$ and computing the formula: $\mathrm{T}[\mathrm{K}]=-108.33 \Delta \delta+460.41$ according to $\mathrm{S}$. Berger and $\mathrm{S}$. Braun, in 200 and More NMR Experiments, Wiley-VCH, Weinheim, $3^{\text {rd }}$ ed., 2004, pp. 145-148. 